\title{
Guatemala: Report on Observance of Standards and Codes- Fiscal Transparency Module
}

This Report on the Observance of Standards and Codes on Fiscal Transparency for Guatemala was prepared by a staff team of the International Monetary Fund as background documentation for the periodic consultation with the member country. It is based on the information available at the time it was completed on December 19, 2005. The views expressed in this document are those of the staff team and do not necessarily reflect the views of the government of Guatemala or the Executive Board of the IMF.

The policy of publication of staff reports and other documents by the IMF allows for the deletion of market-sensitive information.

To assist the IMF in evaluating the publication policy, reader comments are invited and may be sent by e-mail to publicationpolicy@imf.org.

Copies of this report are available to the public from

International Monetary Fund $\bullet$ Publication Services

700 19th Street, N.W. • Washington, D.C. 20431

Telephone: (202) $6237430 \bullet$ Telefax: (202) 6237201

E-mail: publications@imf.org • Internet: http://www.imf.org

Price: $\$ 15.00$ a copy

\section{International Monetary Fund \\ Washington, D.C.}



INTERNATIONAL MONETARY FUND

\title{
GUATEMALA
}

\section{Report on the Observance of Standards and Codes (ROSC) Fiscal Transparency Module}

\author{
Prepared by the Fiscal Affairs Department
}

\author{
Approved by Anoop Singh and Teresa Ter-Minassian
}

December 19, 2005

\begin{abstract}
EXECUTIVE SUMMARY
This report provides an assessment of fiscal transparency practices in Guatemala in light of the requirements of the IMF Code of Good Practices on Fiscal Transparency, based on discussions with the authorities and other organizations, the authorities' response to the IMF fiscal transparency questionnaire, and other sources of information. The IMF Manual on Fiscal Transparency (http://www.imf.org/external/np/fad/trans/manual/) should be consulted for further explanation of the terms and concepts discussed in this report.

Guatemala has progressed in certain important aspects of fiscal transparency. First, the adoption of the Integrated Financial Administration System (SIAF) by all institutions in the Executive Branch and more than half of the decentralized and autonomous agencies, the introduction of a municipal version of this system (SIAF-MUNI) in 36 municipalities by 2004 (and a plan to extend its coverage to almost 100 municipalities by end-2005), and the use of SIAFITO-MUNI in almost all the municipalities, the development of the Government Audit System (SIAF-SAG) by the Office of the Comptroller General of Accounts (CGC), and the obligatory adoption of the Public Sector Procurement and Contracting Information System (GUATECOMPRAS) have made it possible to modernize budget, treasury, and accounting procedures, improve management and control of public funds, and prepare timely budget execution reports. They will also facilitate external audits and make public procurement procedures more transparent. Second, the annual budget and the ministry of finance (MINFIN) website provide increasingly complete information on central government (executive branch) activities, including information on tax expenditure and indebtedness, and multiyear budget scenarios. Lastly, recent regulatory changes (the Municipal Code, the Organic Law of the Bank of Guatemala, a series of laws related to financial activities - the Law on Banks and Financial Groups, the Financial Supervision Law, and the Law on Free Foreign Exchange Trading - and the Law governing the CGC have clarified intergovernmental fiscal relations and those between the government and the central bank. They have also strengthened banking supervision and the capital of financial institutions, thereby reducing the risk of fiscal contingencies, and they have redefined the structure and functions of the CGC, in an effort to render it more effective.
\end{abstract}

Improvement is still needed in a number of areas, however, some requiring amendments to laws or the constitution. The mission's main recommendations are: adoption of an institutional classification of public entities conforming to international standards and adapting budget and reporting coverage to match that classification; preparation of consolidated public sector budgets and accounts; improvement of multiyear budgeting, tied to performance indicators and goals and linked to the annual budget preparation process, a practice that was initiated for the 2006 budget; identification, quantification, and reporting of contingencies and quasi-fiscal activities; clearer definition and demarcation of the powers to amend budgets between the executive and legislative branches; gradual reduction of the use of funds and fiduciary instruments for expenditure management, as these detract from the transparency of the budget process; reduction of the number of activities and entities that are exempted from the provisions of the law on public procurement and the use of GUATECOMPRAS; precise demarcation of the spheres of competence of the central government, the development councils, and the municipalities on investment prioritization; guarantee of legal protection of the tax administration from political interference; clear and easily verifiable criteria for distributing transfers to the municipalities; the establishment of more robust mechanisms for enforcement of reporting of budgets and municipal debt; and stronger external control through enhanced training in the use of information systems, wider dissemination of findings, and stricter monitoring of audit recommendations. 


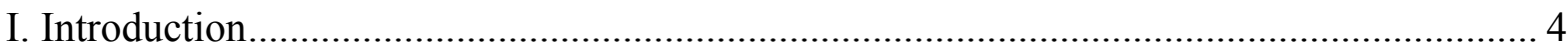



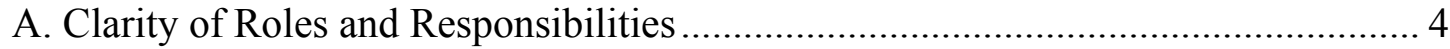



C. Open Budget Preparation, Execution, and Reporting ..................................... 20

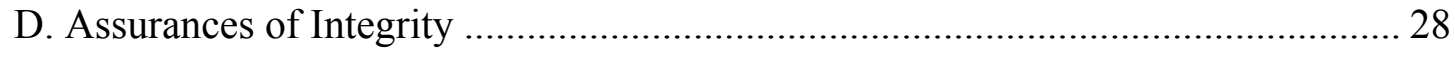

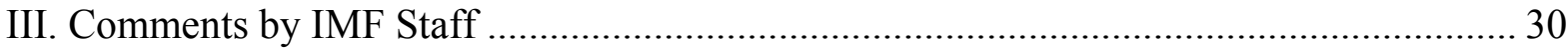

Tables

1. Reporting Obligations of Public Institutions................................................................. 17

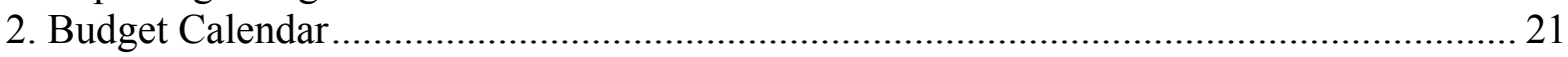

Appendices



II. Public Availability of Information-A Summary …............................................... 38 


\section{ACRONYMS}

\begin{tabular}{|l|l|}
\hline BANGUAT & Bank of Guatemala (www.banguat.gob.gt) \\
BANRURAL & Rural Development Bank \\
CACIF & Coordination Committee of Agricultural, Commercial, \\
& Industrial, and Financial Business Associations \\
CDR & Congress of the Republic \\
CGC & Office of the Comptroller General of Accounts \\
CHN & National Mortgage Bank \\
CIEN & National Economic Research Center (www.cien.org.gt) \\
DCE & Government Accounting Directorate \\
DO & Official Gazzette \\
DTP & Technical Directorate of Budget \\
EEGSA & Electricity Enterprise of Guatemala \\
FIS & Social Investment Fund \\
FOGUAVI & Guatemalan Fund for Housing \\
FONTIERRA & Land Fund \\
GUATEL & Guatemalan Telecommunications Enterprise \\
INACOP & National Institute of Cooperatives \\
INDE & National Electrification Institute \\
INFOM & Municipal Development Institute \\
INGUAT & Guatemalan Tourism Institute \\
LOP & Organic Budget Law \\
MINFIN & Ministry of Public Finance (www.minfin.gob.gt) \\
ONSEC & National Office of the Civil Service \\
PGIEE & General State Revenue and Expenditure Budget \\
SAG & Government Audit System \\
SAT & Superintendency of Tax Administration (www.sat.gob.gt) \\
SEGEPLAN & Secretariat of Planning and Programming of the Presidency \\
SIAF & Integrated Financial Administration System \\
SICOIN & Integrated Accounting System \\
SNIP & National Public Investment System \\
UDAF & Financial Administration Unit \\
UDAI & Internal Audit Unit \\
\hline
\end{tabular}




\section{INTRODUCTION}

1. This report provides an assessment of Guatemala's fiscal transparency practices in light of the requirements of the IMF's Code of Good Practices on Fiscal Transparency. ${ }^{1}$ The assessment is divided into two sections. The first section contains a description of practices, prepared by IMF staff based on consultations with the authorities and other organizations, the authorities' replies to the questionnaire on fiscal transparency, and additional available information. The second section consists of comments by IMF staff on fiscal transparency in Guatemala.

\section{Description of Practices}

\section{A. Clarity of Roles and Responsibilities}

\section{Definition of government activities}

\section{The definition of the government sector has only been partially adapted to the} IMF's Government Finance Statistics Manual (GFSM).

By law, ${ }^{2}$ Guatemala's public sector is comprised of the central government, nonfinancial public enterprises, public financial institutions, and local governments. ${ }^{3}$ The central government is comprised of the central administration, decentralized nonbusiness agencies, autonomous nonbusiness agencies and social security institutions. The central administration includes the legislative branch (Congress of the Republic), the judicial branch (headed by the Supreme Court of Justice), a series of constitutional bodies, ${ }^{4}$ and the executive branch comprising the President and Vice President of the Republic, to which 6 secretariats, 17 support agencies, and 13 ministries report. The concept of central government in the GFSM of the IMF coincides with the above-mentioned central administration of the Manual of Budget Classifications for the Public Sector of Guatemala (MCPSP). The relevant concept of government in Guatemala, however, from the standpoint of budget and fiscal statistics, is that corresponding to the executive branch of central government. ${ }^{5}$

\footnotetext{
${ }^{1}$ The report was prepared by Messrs. Israel Fainboim, Patricia Alborta, and Juan Tejedor. It updates and complements a preliminary draft prepared by Messrs. Peter Kohnert and Julio Viñuela in 2003.

${ }^{2}$ Ministerial Resolution 215-2004 of December 30, 2004 approving the MCPSP.

${ }^{3}$ There are currently 18 decentralized nonbusiness entities; 5 nonbusiness autonomous agencies; 2 social security institutions; 9 Guatemalan public enterprises, 331 municipal governments; 8 municipal public enterprises; 1 nonbusiness municipal institution; and 1 municipal social security institution. There are also 4 central government, 2 banking, and 2 nonbank financial public institutions, one of which is in the process of liquidation.

${ }^{4}$ Office of the Controller General of the Republic, Office of the Attorney General for Human Rights, Office of the Attorney General (Ministerio Público), Electoral Supreme Court, Court of Constitutionality, Criminal Public Defense Institute, and General Property Register.

${ }^{5}$ The budget and fiscal statistics only include central government contributions to the legislative and judicial branches and to the decentralized and autonomous agencies, not their full budgets. Obviously, the legislature has no own revenues, and they are very small for the judiciary.
} 


\section{The Congress of the Republic only approves the budget of the central government} institutions comprising the executive branch. The legislative and judicial branches and autonomous agencies prepare their own draft budgets, which are then approved by their highest authorities in the time allowed and via the mechanism specified in their organic laws. The decentralized agencies have to submit their draft budgets, via the MINFIN, for consideration by the executive branch, which has to issue the corresponding government resolutions approving them by the December 15 prior to the start of each fiscal year (Article 40 of the Organic Budget Law (LOP). According to the Constitution (Articles 134 and 237) and the LOP, all these agencies (and the municipalities) must submit their budgets to the executive branch and to the Congress of the Republic for their information and for inclusion in the general state revenue and expenditure budget (PGIEE). ${ }^{6}$ Neither the autonomous nor the decentralized agencies operate on the market. They perform government functions and are financed almost entirely by central government grants. ${ }^{7}$ Their boards are appointed by the president or the ministers, and in some cases they include the ministers themselves. Given these characteristics, there is no justification for excluding them from the regular budget process. ${ }^{8,9}$ The decentralized and autonomous agencies may contract debt within individual ceilings that the MINFIN has to establish; and in some cases the national government guaranteed their debt.

\section{The government currently owns few public enterprises and few stocks in private or mixed capital enterprises. \\ 1.1.5, 2.1.4}

\footnotetext{
${ }^{6}$ The municipalities do not comply with this requirement, because no sanctions are imposed for failure to submit information. Municipal governments approve their budgets at the end of December and only some of them submit them to the executive for its information at the beginning of the fiscal year.

${ }^{7}$ The MCPSP defines decentralized agencies as those that act under the authority of the central government, with a certain degree of independence as regards their legal status and responsibilities, to perform specialized government functions. It defines autonomous agencies as those that are free to be governed by their own laws and have their independent legal status and their own patrimony, recognizing that in some cases autonomy is only functional. Furthermore, the manual mentions that the purpose of both types of agency is not to market the goods and services they produce. The existing autonomous agencies mainly conduct educational activities [San Carlos University (USAC), the Central National College of Agriculture (ENCA), the Mayan Languages Academy (ALMG)], or promote sports [the Guatemalan Olympic Committee (COG), the Autonomous Sports Confederation of Guatemala $(\mathrm{CDAG})]$. The decentralized agencies have more varied missions and include institutions such as the Municipal Development Institute (INFOM), the National Institute of Statistics (INE), the Guatemalan Tourism Institute (INGUAT), the National Institute of Cooperatives (INACOP), the Land Fund (FONTIERRAS), and the Superintendency of Tax Administration (SAT).

${ }^{8}$ In 2005, the budget of the decentralized agencies amounted to Q 1,322.2 million (equivalent to 4.5 percent of the budget of the executive branch of central government), that of the autonomous agencies was Q 804.0 million (2.7 percent), that of the Judiciary Q 1,246 million (4.2 percent), and that of the Legislature Q 260.2 million (0.9 percent), compared to a total budgeted amount of Q 29.679 million. Of the budgets of these agencies, the PGIEE includes national government contributions, which accounted for 80 percent of the budget of the decentralized agencies, 98.6 percent of the autonomous agencies, 100 percent of the legislature, and 95.4 percent in the case of the Judiciary.

${ }^{9}$ With the exception of the Universidad de San Carlos, that should be excluded.
} 
The privatizations carried out in the second half of the 1990s substantially reduced the scope of the government's enterprise sector. ${ }^{10}$ Currently, the government owns nine nonfinancial public enterprises ${ }^{11}$ and stocks in two nonfinancial private enterprises; ${ }^{12}$ it also owns four financial institutions, two of which are banks ${ }^{13}$ and two are nonblank institutions ${ }^{14}$-one of which is in the process of liquidation. With the exception of the port authorities and INDE, the remaining seven nonfinancial enterprises are small and almost all of them show losses and require government transfers to be able to operate. ${ }^{15}$ One of them, PROLAC, was handed over to a cooperative, for the latter to manage; FEGUA ceased performing its principal function and administers a concession to the private sector; and ZOLIC lost all its assets. ${ }^{16}$ One of the financial enterprises, $\mathrm{CHN}$, is in financial distress, partly as a result of its forced merger (in 2002 and 2003) with two undercapitalized financial institutions. There is no government entity responsible for monitoring the performance of the enterprises and for coordinating policy to meet their needs.

\footnotetext{
${ }^{10}$ While the first major privatization took place in 1989, with the sale of Aviateca, and the next in 1997, with the sale of some thermo electrical plants, most privatizations were carried out in 1998. They includes the sale of 95 percent of TELGUA (to which most GUATEL assets had to be transferred in order to be able to privatize the latter, leaving GUATEL with just the rural public telephony network), the licenses to operate cellular mobile telephone services, the railroad transportation concession, the sale of part of BANRURAL, the splitting of INDE's distributors into two enterprises (DEOCSA and DEORSA) and the sale of a portion of them, and the sale of 80 percent of EEGSA. Frequency bands were also sold to a number of enterprises. The privatizations generated approximately US\$3 billion in revenue for the government. The proceeds from the sale of DEORSA and DEOCSA (US\$110 million) were deposited in a trust fund, which was used to finance a five-year rural electrification program, which these two enterprises were asked to execute. In the telecommunications sector, 70 percent of the revenue from auctioning frequencies (up to a ceiling of US\$5.0 million per annum) was assigned to a special fund (FONDETEL), which was administered by a trust. The funds were earmarked for expansion of rural public telephony. GUATEL is responsible for managing two of the four rural telephony expansion contracts.

${ }^{11}$ Guatemalan Telecommunications Enterprise (GUATEL), the Free Trade and Industry Area of Santo Tomás de Castilla (ZOLIC), the Santo Tomás de Castilla Port Authority (EMPORNAC), the Quetzal Port Authority (EPQ), the Champerico National Port Authority (EPNCH), the Guatemalan Railroads (FEGUA), the National Agricultural Marketing Institute (INDECA), the Dairy Products Enterprise of Asunción Mita (PROLAC), and the National Electrification Institute (INDE). This last-mentioned enterprise is, in turn, a shareholder in ORSUNIL, a steambased electricity generator.

${ }^{12}$ Electricity Enterprise of Guatemala (EEGSA) and EXMIBAL.

${ }^{13}$ National Mortgage Bank (CHN) and Rural Development Bank (BANRURAL). The government has a minority stake in BANRURAL.

${ }^{14}$ Institute for the Promotion of Insured Mortgages (FHA) majority-owned by CHN) and National Financial Corporation (in liquidation).

${ }^{15}$ The enterprises that pose fiscal risks for the government should be monitored and consolidated in the fiscal reports.

${ }^{16}$ Its installations were completely destroyed in a fire.
} 
$\underline{\text { Relations between the government and the nonfinancial public enterprises and the private }}$ $\underline{\text { sector }}$

5. The government has used public enterprises as a fiscal policy tool.

INDE carries on major quasi-fiscal activities, which are seriously undermining its financial position. Until 2004 the enterprise granted electricity rate subsidies for households consuming fewer than $300 \mathrm{kWh}$. per month as it is required to have a "social rate;" 17 currently the subsidy applies for households consuming below $100 \mathrm{kWh}$. per month. It grants private distribution companies concessions for works in poor and remote parts of the country without recovering its investment cost and builds transmission lines to nonprofitable areas. It pays for works and for electricity provided by other countries in border zones and, during a time of rationing, signed guaranteed electricity purchase contracts with private generating companies at a rate that is currently far above the market price. ${ }^{18}$ These subsidies are not offset by central government transfers. The government only funds rural electrification, using the proceeds from the privatization of its distribution companies (see footnote 9).

6. There are clear rules governing transfers of public enterprise earnings to the government, but they are specific to each enterprise and can be amended at the discretion of congress. The profits distribution rules are set forth in the respective organic laws creating each enterprise that were passed by congress and can be changed by congress at will. That is why the dividend policies are so heterogeneous ${ }^{19}$ and why some of the amendments to these rules are not the result of corporate strategy, but rather of pressure exerted by various power groups (the interests of regional politicians, trade unions, etc.).

\section{There is no legal framework to govern privatization. Some privatization processes have not been transparent.

The enterprises were privatized using ad hoc mechanisms; in some cases they were sold directly and in others via a public tender. Public competitive bidding was used to sell the two distribution companies belonging to INDE. GUATEL's assets were sold directly in an operation that, like the railroad concession, is not considered transparent. In the telecommunications sector, there were specific rules for the frequency band auctions.

\section{The laws and procedures establishing government regulation of the nonfinancial private sector are complex and cumbersome; interested parties are consulted prior to approval of new regulations.

\footnotetext{
${ }^{17}$ Since the ceiling was initially set too high in relation to average residential consumption (which is about $100 \mathrm{kWh}$ per month), 99 percent of residential clients qualified for the social rate, which means that the size of the subsidy was considerable (it was estimated at around US\$60 million a year).

${ }^{18}$ In these contracts, INDE took high risks, since they are indexed to the price of oil and to the U.S. dollar.

${ }^{19}$ For instance, while the Puerto Quetzal enterprise has rules allowing the government, some municipalities, and the workers to share earnings, INDE has to reinvest all of them and GUATEL's rules do not provide for earnings to be distributed to municipalities. However, all distribution rules do stipulate that earnings be distributed to the workers, for reinvestment, and for the retirement reserve.
} 
The activities of commercial enterprises are governed by the Commercial Code (Decree No. 270 of January, 1970). Other important rules governing private sector activities are: the Law on Banks and Financial Groups (Decree No. 19-2002), the General Law of Electricity (Decree No. 93-96), the General Law of Telecommunications (Decree No. 94-96), the Transportation Law (Decree No. 253), the Foreign Investment Law (Decree No. 9-98) and the Hydrocarbons Law (Decree No. 109-83). Those seeking to establish and operate a business in Guatemala or to invest in one face serious obstacles, ${ }^{20}$ due to the excessive number of requirements, lack of key information, and the difficulty of enforcing contracts, owing to the slow pace and unpredictability of the judicial system. Regulation of public utilities is incomplete and is used to subsidize users. ${ }^{21}$ There is no legal obligation to submit draft private sector regulations to prior hearing procedures. The interested parties, however, are generally consulted prior to approval.

Government relations with the central bank and the financial public sector

\section{Even though a recent law increased its autonomy, the Bank of Guatemala (BANGUAT) is not fully independent of the government. It has not financed government operations, but it engages in other quasi-fiscal activities; and it does not pay interest on government deposits.

The determination of monetary, exchange, and credit policy and the definition of its objectives are the responsibility of the Monetary Board ${ }^{22}$ and the BANGUAT is technically autonomous to execute this policy through an execution committee comprised of authorities from BANGUAT appointed by the Monetary Board at the proposal of its chair. The latter is

\footnotetext{
${ }^{20}$ Although the time it takes to start a business in Guatemala (39 days) is less than the average for the countries in the region (70 days), whereby the most time-consuming requirements are registration in the government's registry of businesses concerns (Registro Mercantil) and publication of a notice in the Official Gazette (Diario Oficial), the notarial costs involved are very high. As regard to credit availability, the law does not guarantee that borrowers can inspect the data in their credit record. The time needed to enforce a contract in the courts is much higher than the regional average and involves a greater number of procedures. Liquidating a business (adjudication of bankruptcy) takes a long time (4 years), compared to 3.7 years in the region, and is very costly. At the same time, investors are not adequately protected because neither financial data nor information on the ownership of enterprises nor decisions taken at shareholders' meetings are published and companies are not obliged to undergo an external audit. Labor legislation dates back to 1961, is rigid with regard to flexibility in hiring and firing workers and working conditions, and establishes high social security benefits. The cost of dismissing workers is high and the prior notice requirement practically guarantees job stability by preventing immediate dismissal. (Information taken from the World Bank and International Finance Corporation (IFC) web page entitled "Doing Business" and from the document CIEN, 2004, Politicas Laborales en Centroamerica. Oportunidades o barreras para el desarrollo?

${ }^{21}$ One such example is the establishment of the above-mentioned "social rate" in the electricity sector, which has led to a considerable drop in demand for electricity from private enterprises, as well as to a deterioration in the financial position of INDE.

${ }^{22}$ The Monetary Board is chaired by the President of Bank of Guatemala and is comprised of the president of the bank, appointed by the President of the Republic, the ministers of public finance, economy, and agriculture, livestock and food, one members elected by the Congress of the Republic, one member appointed by the business associations, one representative of the private banks, and one member elected by the Higher Council of the University of San Carlos de Guatemala (Article 132 of the Constitution).
} 
appointed by the President of the Republic for a four-year term, and these terms overlap with two successive government terms. The chair reports to congress twice a year. The bank is a decentralized autonomous institution that prepares and approves its own budget. According to the constitution, BANGUAT is not allowed to finance the government. ${ }^{23}$ In the recent past, the bank was obliged to conduct bailout operations for some banks, without it being compensated for that activity by the government. ${ }^{24}$ Although the law establishes that the government must cover BANGUAT losses, in practice it has only done so to a minor extent. ${ }^{25}$ BANGUAT collects fees for its fiduciary services and those it performs as the financial agent of the state, but it does not remunerate the government's deposits at the bank. ${ }^{26}$

\section{Although the government's equity share in financial institutions is small, quasi-} fiscal activities of these institutions have been significant. In 2002 and 2003, the CHN was obliged to acquire two troubled banks, one private, the other public. In 2003, the government increased the bank's capital to enable it to withstand these absorptions, but the operation was not sufficient to prevent the deterioration of its financial situation. ${ }^{27}$

\footnotetext{
${ }^{23}$ Article 133 states that "the Monetary Board may not authorize BANGUAT to grant direct or indirect financing or issue guarantees or endorsements to the state or to its decentralized or autonomous agencies, or to the nonbank private sector; nor, for the same reason, may it acquire securities that are issued or traded on the primary market by said entities."

${ }^{24}$ Between 1998 and 2001, it provided credits in the amount of Q 4,531 million to banks that were ultimately placed under government administration; of that amount, BANGUAT has recovered Q 2,476 million.

${ }^{25}$ According to the Organic Law of the Bank of Guatemala (Decree No. 16-2002), the government had to cover losses accumulated through December 2001 by issuing long-term debt instruments, an operation that has not been approved by the Congress of the Republic; and the net annual shortfalls resulting from monetary and exchange policy in the following years have only been partially absorbed by the government. Accumulated losses through 2001 were estimated at Q 16 billion, for which the bank is scheduled to receive an overall 100-year bond. The net shortfalls of the past three years were, respectively, Q 905.3 million in 2002, 963.7 million in 2003 and 1063.1 million in 2004. The amount corresponding to 2002 was included in the draft budget for 2004, which was not, however, approved by congress, whole that for 2003 was included in the draft 2005 budget and was approved.

${ }^{26}$ Article 55 of the Organic Law of the Bank of Guatemala establishes that it shall not pay interest on public sector deposits held at the bank. The bank, for its part, does not charge for the financial operations it conducts for the public sector. In return for acting as the state's financial agent, the bank charges a fee of one quarter of one percent (1/4 of 1 percent) per year on the balance of outstanding T-bills, on the last business day of each month, excluding the equivalent in quetzals of issues placed on the international financial market. BANGUAT also acts as the trustee of the trust funds set up in the bank by the government. For that, it charges a management commission (administrative fees), payable each month, which range from 0.25 percent and 1.0 percent a year, calculated on the balance of the assets in the trust fund.
}

${ }^{27}$ The bank's executives estimate that it needs an additional capital injection of Q 500 million to achieve sound capital adequacy ratios. 
$\underline{\text { Fiscal relations between the branches of government }}$

11. The separation of roles and responsibilities between the executive and legislative branches with respect to the budget is clearly defined in the constitution, but it is does not allow an appropriate assignment of responsibilities in connection with fiscal policy. 1.1 .2 According to the constitution, the executive branch, through the MINFIN, must submit the draft budget to congress at least 120 days before the beginning of the fiscal year and congress is required to approve, amend, or reject the draft no later than 30 days prior to the start of the next fiscal year (November 30). If the budget has not been approved by the beginning of the fiscal year, the budget in effect on December 31 of the prior year, modified or adjusted as required by congress, will again take effect. The legislative branch has unlimited power to amend the draft budget, be they cuts or increases, and it may also amend the general standards governing execution. ${ }^{28}$ These powers have frequently been used to modify the aggregate income and expenditure figures, their allocation among priorities, and even the fiscal balance (deficit/surplus). In some years, congress increased expenditure by as much as 20 percent. $^{29}$ This situation makes it quite difficult to attribute responsibility for the fiscal policy that is applied. Although the president has overall veto power over the budget approved by the legislative branch, congress may override it with a two-third majority vote of the total number of members; and, in practice, this veto has never been exercised.

\section{The executive's authority to make inter- and intra-institutional amendments to the} budget is fairly extensive. They are regulated by Articles 238 and 240 of the Constitution and Article 32 of the LOP. Article 238.b. of the Constitution delegates to the LOP regulation of "cases in which funds may be transferred within the total allocated to each agency, dependency, and decentralized or autonomous institution. Item transfers shall be reported immediately to the Congress of the Republic and to the CGC." Article 32 of the LOP authorizes the executive to make budget amendments, including inter-institutional transfers, provided that they do not affect the ceiling approved by congress. The ministries may make intra-institutional budget amendments, authorized by a resolution of the head of the institution concerned, provided that they do not entail changes in the sources of funding, transfers between investment programs or projects, or modifications to the allocations for personnel services. Amendments in the last three above-mentioned items require a MINFIN resolution. Inter-institutional transfers require a government resolution (Acuerdo Gubernativa), issued by the President of the Republic and endorsed by the heads of the institutions concerned. Amendments are frequently made by the executive, which means that the approved budget has become less of a benchmark for public policies.

\footnotetext{
${ }^{28}$ Article 171.b of the Political Constitution.

${ }^{29}$ Congress reduced income, expenditure, and the deficit in the draft 2001 budget by 7.8 percent, 9.1 percent, and 11.0 percent respectively. This did not prevent it from approving in the same year increases of expenditure of approximately 11.9 percent vis-à-vis the initially approved amounts. In 2002, it made cuts of 4.9 percent, 8.5 percent and 30 percent, respectively, while in 2003, an election year, it raised expenditure by 9.4 percent, which entailed increasing the proposed deficit by approximately 70 percent. The draft 2004 budget was not approved by congress, while that for 2005 had its revenues increased in 1 percent, its expenditures in 2 percent and the deficit in 8.6 percent.
} 


\section{There is a clearer demarcation of powers to approve laws that increase public} expenditure. Article 240 of the Constitution establishes that "any law that involves investment and government expenditure must indicate the source of the funds to be used to pay for them. If the investment or expenditure are not included and identified in the general state revenue and expenditure budget approved for the fiscal year in question, the budget may not be increased by the Congress of the Republic without the assent of the executive." The same article adds that if the executive dissents, congress could approve a budget amendment through a two-third majority of all legislators.

\section{$\underline{\text { Fiscal relations among different levels of government }}$}

\section{The roles and responsibilities of the different levels of government are clearly defined.

The Municipal Code (Decree No. 12-2002) and the Decentralization Law (Decree 14-2002) clearly indicated the municipalities' spheres of competence. These are very limited and consist basically of (i) management of pre-school and primary education, and of literacy and bilingual education programs; (ii) regulation and provision of municipal public utilities, including drinking water, sewerage, street lighting and cleaning; (iii) construction and maintenance of urban streets; (iv) licensing of public construction works; (v) the police; and, (vi) environmental management of the municipality's natural resources (Title V, Chapter I of the Municipal Code). The General Law of Decentralization (Decree No. 14-2002)

contemplates reassigning health and social work functions to the municipalities (Article 7), but it does not establish a timetable for the transfer, nor for the amounts of funds to be transferred to ensure that these functions can be carried out.

15. The distribution of transfers to the municipalities under the constitution and other specific laws is based on ambiguous criteria, and the data on own revenues needed to apply them are not systematically verified. The municipalities receive transfers from a number of sources: (i) a constitutional contribution, equivalent to 10 percent of the state's general ordinary revenue; ${ }^{30}$ (ii) 1.5 percentage points of the VAT rate; (iii) a percentage of vehicle tax revenue; (iv) Q 0.20 of revenue from the tax on each gallon of gasoline; and (v) a percentage $^{31}$ of the real estate tax (Impuesto Único sobre Inmuebles-IUSI). Additionally, they receive cofinancing from the social funds and development councils for investment projects. The criteria laid down in the Municipal Code $^{32}$ are used to distribute the resources of the first four sources mentioned above (which in recent years have accounted for approximately

\footnotetext{
${ }^{30}$ Ordinary revenue has been defined in Guatemala as tax revenues that are not directly earmarked in specific laws.

${ }^{31}$ Municipalities that collect the IUSI themselves keep 100 percent of the revenue.

${ }^{32}$ Namely: (i) 25 percent to be shared equally among the municipalities; (ii) 25 percent in proportion to the population of the municipality; (iii) 25 percent in proportion to ordinary income per capita; (iv) 15 percent in proportion to the number of villages and hamlets; and (v) 10 percent in inverse proportion to ordinary income per capita.
} 
1.2 percent of GDP) among the municipalities. These criteria have the disadvantage of reducing the incentive for municipalities to increase their tax effort. ${ }^{33}$ They also depend on information on own revenues provided by the municipalities that is not systematically verified. Moreover, the criteria used are such that a modification in the value of one of the variables may result in unpredictable changes and a high degree of volatility in the transfers. ${ }^{34}$

16. The municipalities do not have tax autonomy; their tax structure is obsolete and composed of a number of taxes that are unlikely to yield much revenue. Municipal taxes were in many cases approved over 25 years ago; there are problems with implementing and administering the IUSI, little use of contributions for improvements, and public utility rates are set at levels that do not cover costs. Only the municipal tax on street lighting has proved to be dynamic and to cover costs. The Municipal Tax Code, which strengthens the capacity to generate own revenues and reduces dependency on central government transfers, has not been approved.

$\underline{\text { The legal and administrative framework for budget management }}$

\section{The legal framework for administering public funds is clear, but has a number of} shortcomings.

The constitution regulates the principles of legality, universality, unity, publication, nonearmarking of revenue, gross budget, and annual budget principles. It provides for an LOP to regulate the budget system and determines the minimum required content of the law. The LOP regulates the budget, accounting, treasury, and public credit systems, set out in detail in the regulations. However, none of the relevant texts contains a clear regulation specifying the required PGIEE coverage. While the LOP provides that the executive body must prepare the multiyear budget (Article 8), there is no text that specifies the objective, content, and coverage of that budget. The legal framework includes few provisions on transparency and addresses only the obligation to publish regulations approving the PGIEE and those of decentralized and autonomous agencies in the Diario Oficial. References in the law to the requirement to prepare consolidated budgets and outturn reports for the public sector have not been developed, and are, therefore, not complied with.

18. The mechanisms for coordinating and managing budget and extrabudgetary activities are inadequately defined.

A large number of institutions that should be part of central government according to the definition in the IMF's GFSM are not included in the regular budget process. ${ }^{35}$ Part of the

\footnotetext{
${ }^{33}$ A percentage is allocated in direct proportion to ordinary income, while another is assigned in inverse proportion.

${ }^{34}$ See, for example, CIEN, 2001, La Distribución de las Transferencias del Gobierno Central a las Municipalidades: Evaluación y Propuesta [Distribution of central government transfers to the municipalities: assessment and proposal], August, in which tests of sensitivity to changes in variables show that such changes produce unpredictable changes in transfers.

${ }^{35}$ The autonomous and decentralized agencies and the legislative and judicial branches.
} 
budget is channeled through funds and much use is made of the trust fund mechanism ${ }^{36}$ to execute a large part of the funds for which no reports are produced. ${ }^{37}$ The use of funds and trusts detracts from the transparency of the budget process, creates rigidities within the budget, and increases cash management costs to the treasury. In addition, there are grants from bilateral agencies that are initially not reflected in the budget, which are spent and subsequently regularized by means of amendments.

$\underline{\text { Legal and administrative framework for tax policy and administration }}$

19. Tax legislation is complex, comprehensive, and scattered over a wide range of rules and regulations. The legal framework is also unstable, as a result of decisions taken by the Constitutional Court.

Although the procedural and penalizing regime is set forth in the Tax Code (Decree No. 6-91), each tax is governed by a specific decree and there is no rule or regulation that compiles them and guarantees their consistency. With a view to achieving the goal established in the Peace Agreements of a tax effort equal to 12 percent of GDP, several tax reform proposals have been put forward over the past seven years, some of which have been declared unconstitutional, forcing the government to present alternative proposals. This has created considerable instability with respect to regulations. ${ }^{38}$ The sworn tax return mechanism is practically the general rule; only in one case is the presumed tax-base system applied. While the clarity of the regulations provides a setting in which taxpayers' sworn returns can be effective, jurisprudence is still weak in the sense that there are no arrangements for tax auditors to get together in committee and establish jurisprudence based on taxpayers' consultations. As a result, there are differences in interpretation.

\section{Tax exemptions are substantial and tax expenditures are reported by the authorities.}

The number and scope of tax exemptions are considerable. They cannot be granted on a caseby-case basis. In the case of income tax, the most significant are: (a) deductions from personal income tax, such as the lump sum of Q 36,000; (b) social security contributions; (c) exemptions

\footnotetext{
${ }^{36}$ Some of the funds are decentralized agencies [the social investment fund (FIS) and the national land fund (FONTIERRAS)], but most are just trust funds.

${ }^{37}$ Although Article 59 of the LOP establishes that the institutions that act as trustees in trust funds constituted by government institutions must submit monthly reports to the MINFIN on movements in their accounts, the MINFIN does not receive these reports with the required frequency or punctuality. For 2005, the budget for funds and trust funds constituted 10 percent of the expenditure budget.

${ }^{38}$ The most recent example of how difficult it is to change tax regulations is the case of Decree No. 03-04 of the Congress of the Republic, which amended the Tax Code with respect to information regarding third parties, means of proof, and so on, with a view to facilitating efforts to combat evasion. The Decree was challenged before the Court of Constitutionality by the Coordination Committee of Agricultural, Commercial, Industrial, and Financial Business Associations (CACIF), which resulted in nine of its articles being suspended, while 14 have to be amended. According to former ministers of finance, it is the wording of some Articles in the Constitution that is preventing changes to tax regulations, creating what they have called a "constitutional padlock."
} 
on Christmas bonuses, bonus 14, and personal expenses ${ }^{39}$; (d) educational establishments and government institutions; and (e) export processing zones (empresas maquiladoras) and free trade areas. In the case of the VAT, the major exemptions are for exports and sales of food in cantonal markets for under Q 100. No public information is provided on individual taxpayer exemptions. The tax expenditures associated with the exemptions have been reported since 2003 in the budget documents and on the MINFIN website (www.minfin.gob.gt) and the SAT website (www.sat.gob.gt). These expenditures are calculated once a year, but the methodology for the calculation is not explained.

\section{Tax administration rules are clearly defined and well coordinated with overall} fiscal management.

The powers and limitations of the tax authorities to request information from third parties and enforce payments of tax arrears are set forth in the Tax Code (Decree No. 6-91). Treatment of much of the information needed for audits as confidential hampers collection of tax debts. The superintendency of tax administration (SAT) was established as a decentralized institution, with functional, economic, technical, and administrative autonomy, its own legal status, patrimony, and resources; and with authority and jurisdiction throughout the national territory. It is structured according to function. ${ }^{40}$ There is a single taxpayer identification number (NIT), which is used by all tax administration units and for all taxes. The SAT's workplace regulations ${ }^{41}$ include, among other things, rules of a technical and administrative nature needed to ensure that the institution functions properly: the disciplinary code for staff and other employees, the general principles and policies to be considered when issuing regulations, procedures, and instructions to do with personnel administration, and so on. In addition, Resolution No. 142-2000 issued a code of ethics for public servants in the SAT aimed at fostering an institutional culture opposed to corrupt practices. The aforementioned rules apply to all SAT employees.

\section{Taxpayers' rights are well defined.}

These rights are set forth in the tax code. Taxpayers have a right to a hearing to express their agreement or disagreement with decisions by the tax authority to adjust their taxes or with penalties. They are also given time to produce all means of proof allowed by law (Article142) and may appeal for a reversal or reconsideration of decisions taken by the tax authority. In the last instance they have the right to judicial recourse. ${ }^{42}$ Furthermore, according to Article 102 of

\footnotetext{
${ }^{39}$ The exemption of personal expenses erodes completely the tax base of the personal income tax.

${ }^{40}$ Its structure and internal organization were established in its Internal Rules of Procedure (Resolution No.2-98 of the Board of Directors of the SAT), which created Customs, Collections and Management, and Audit divisions (Intendencias). It also establishes a Coordination Office for Special Taxpayers and four Regional Coordination Offices.

${ }^{41}$ Approved by its Board of Directors in Resolution No. 7-98 of December 1998. In addition to these regulations, the provisions contained in the Labor Code of the Republic of Guatemala also apply.

${ }^{42}$ Tax administration procedures are generally initiated by the SAT (although a taxpayer may also initiate one) with verification of tax returns and tax payment documents. If they are not in order, the SAT prepares a provisional assessment, with such adjustments as may be needed, and notifies the taxpayer, indicating the factual and legal grounds for its decision. Once the taxpayer has been notified, in the case of adjustments he or she has the
} 
Decree No.6-91, the tax authority must attend to any queries it receives from persons with a personal and direct interest in connection with a specific tax situation, regarding application of the code and the tax laws. Presentation of a query does not exempt the person submitting it from timely fulfillment of his or her tax obligations. The reply to the query does not have resolution status, and may not be challenged or appealed in any way. It is only binding for the tax authority in the concrete case it was specifically consulted about. The reply must be issued within 60 business days of the presentation of the query.

\section{$\underline{\text { Public servants code of behavior and anti-corruption activities }}$}

\section{Civil servants are subject to a well defined code of conduct, but the rules and regulations are not applied.}

The Law on the Civil Service ${ }^{43}$ establishes obligations and prohibitions for public servants, but the law does not apply to many institutions that have their own law. Some rules of behavior are included in the constitution, such as the ban on holding more than one government post (Article 112) and freedom not to obey illegal orders (Article 156). The constitution also mentions the civil and criminal liabilities of government officials and employees (Article 155), the responsibilities of the council of ministers (Article 195) and some conflicts of interest and prohibitions for government officials ${ }^{44}$ The Law on Integrity and Responsibilities of Civil Servants and Government Employees ${ }^{45}$ requires all government officials and employees who, by virtue of their job, handle or administer assets or securities, or who in any case earn a monthly salary in excess of a certain amount, to present to the CGC a sworn declaration of all their assets and debts when they take up their post and when they leave it. ${ }^{46}$ The Law on the CGC established a deputy comptroller's office of integrity, charged with verifying compliance with the requirement and checking the veracity of the declarations. The ethical standards of the

\footnotetext{
right, for a 30-day period that cannot be extended, to a hearing to express agreement or disagreement. In the case of penalties, the period is 10 days. The tax laws then allow the same periods of time for presentation of proof. Then actions may be taken to facilitate adjudication within a period of no more than 15 days, so that the SAT has more information on which to base a decision. Finally the taxpayer is notified of the decision in a resolution. The taxpayer may file an appeal for annulment of resolutions issued by the Superintendent (which will be settled by the Board of Directors of the SAT) and for reconsideration of those issued by the Board (to be settled by the Board itself). The taxpayer has 10 business days to file either of these appeals, from the date of the last notification. If the appeal for annulment is denied, he can turn to the higher administrative authority of the SAT within three business days to request that the annulment be granted and the authority shall issue a resolution within 30 days. The same procedure is followed for appeals for reconsideration. If the disagreement persists, the taxpayer has the right to go to the courts.

${ }^{43}$ Decree 1748-68, of May 2, 1968 approving the Law on the Civil Service and its regulation.

${ }^{44}$ On holding the positions of President or Vice President of the Republic (Article 186), congressional representative (Article 164), minister of state (Article 196) and vice minister (Article 201).

${ }^{45}$ Decree No. 89-2002.

${ }^{46}$ The declaration is also obligatory for contractual personnel.
} 
executive branch were issued recently. ${ }^{47}$ They describe the values that should inform public service, the basic duties of civil servants, conflicts of interest, and standards of decorum and public behavior, as well as other rules. However, Guatemalan criminal law does not define illicit enrichment, nor does it contemplate other concepts such as influence-peddling and international bribery; which is a serious impediment in the fight against corruption.

\section{B. Public Availability of Information}

$\underline{\text { Commitment to publish timely fiscal information }}$

\section{The volume of fiscal information made public has increased.}

The information reports established under existing regulations (see Table 1 and the Annex) essentially refer to budget execution, every four months, and at the closure and end of the accounting year. This information is reported separately for the central government and independently for each of the decentralized and autonomous agencies. The constitution establishes that the PGIEE and its outturn are public documents ${ }^{48}$ and requires the executive branch to send congress an analytical report on budget execution every four months. ${ }^{49}$ The PGIEE and the budget of the decentralized and autonomous agencies must be published in the Official Gazzette, an obligation that is regularly met. For its part, the Law on the CGC requires disclosure of which agencies have been audited and of the auditors' findings. ${ }^{50}$ Quite apart from these obligations, it is currently possible to ascertain the status of budget execution by accessing the SIAF website (www.siafsag.gob.gt), which is now installed in all the executive branch agencies and more than half of the decentralized and autonomous agencies, or by consulting the MINFIN website (www.minfin.gob.gt). The MINFIN has also constructed a fiscal transparency page (www.transparencia.minfin.gob.gt) where it publishes fiscal information on a regular basis. Guatemala is now taking the steps needed to participate in the General Data Dissemination System (GDDS). ${ }^{51}$

$\underline{\text { The coverage and quality of budget documents }}$

\section{Budget documents only cover the executive branch of central government and do not provide general government information.

\footnotetext{
${ }^{47}$ Government Resolution No. 197 of July 13, 2004. The standards are in line with commitments undertaken in the interamerican convention against corruption, ratified by the Guatemalan State, and others contained in the Peace Agreements.

${ }^{48}$ Article 237 of the Constitution.

${ }^{49}$ Article 183.w of the Constitution.

${ }^{50}$ Article 9 of the Organic Law of the CGC.

${ }^{51}$ Guatemala complies with the majority of the GDDS recommendations, with the exception of coverage of government finance statistics, which do not encompass consolidated central government or general government. It also does not compile monthly output indices.
} 


\section{Table 1. Reporting Obligations of Public Institutions}

\begin{tabular}{|c|c|c|}
\hline Type of Report & Addressee & $\begin{array}{c}\text { Date and Form of } \\
\text { Publication }\end{array}$ \\
\hline \multicolumn{3}{|l|}{ Executive branch } \\
\hline - President: Analytical report on budget execution. & Congress & Every four months \\
\hline $\begin{array}{l}\text { - Ministers: Activities report, and annual budget outturn of each } \\
\text { Ministry. }\end{array}$ & Congress & $\begin{array}{l}\text { First } 10 \text { days of February } \\
\text { of each year }\end{array}$ \\
\hline \multicolumn{3}{|l|}{ Decentralized and autonomous agencies } \\
\hline - Physical and financial budget management reports. & $\begin{array}{l}\text { MINFIN, } \\
\text { Congress }\end{array}$ & Every four months \\
\hline - Budget outturn and financial statements. & $\begin{array}{l}\text { Congress, CGC } \\
\text { and MINFIN }\end{array}$ & Before March 31 \\
\hline \multicolumn{3}{|l|}{ Municipalities } \\
\hline - Approved budget. & $\begin{array}{l}\text { Congress , CGC } \\
\text { and MINFIN }\end{array}$ & Before January 21 \\
\hline - Physical, financial and budget management report. & $\begin{array}{l}\text { Congress , CGC } \\
\text { and MINFIN }\end{array}$ & Before March 31 \\
\hline $\begin{array}{l}\text { - Breakdown of current external and domestic debts and stock } \\
\text { of debt outstanding. }\end{array}$ & MINFIN, INFOM & Within 10 days of each month \\
\hline \multicolumn{3}{|l|}{ Office of the Comptroller General of Accounts } \\
\hline - List of institutions audited in previous six months. & General public & Half-yearly in Official Gazzette \\
\hline - Outcome of the audit of the institutions. & General public & $\begin{array}{l}\text { When finished, in the Official } \\
\text { Gazzette and CGC Bulletin }\end{array}$ \\
\hline $\begin{array}{l}\text { - Report of the Deputy Comptroller of Integrity on assessments, } \\
\text { analyses, studies, research, etc. carried out. }\end{array}$ & Congress and CGC & $\begin{array}{l}\text { Newspapers, at least twice } \\
\text { a year }\end{array}$ \\
\hline $\begin{array}{l}\text { - Report of the Deputy Comptroller for Quality of Public Expenditure } \\
\text { on assessments, analyses, studies, investigations, etc., carried out. }\end{array}$ & Congress and CGC & $\begin{array}{l}\text { Newspapers, at least twice } \\
\text { a year }\end{array}$ \\
\hline - Management report. & Congress & $\begin{array}{l}\text { Whenever necessary and ex officio } \\
\text { twice a year }\end{array}$ \\
\hline $\begin{array}{l}\text { - Annual audit report on the results of the audits of the } \\
\text { Financial statements and budget execution of Government Finances. } \\
\text { decentralized and autonomous institutions. }\end{array}$ & Congress & 150 days after year-end \\
\hline - Report on tasks, including its budget outturn . & Congress & $\begin{array}{l}\text { First } 10 \text { days of February } \\
\text { of each year }\end{array}$ \\
\hline
\end{tabular}

Source: Prepared by the authors, based on current legislation.

The budget documents provide partial information on central government fiscal activity. ${ }^{52}$ The public revenue included in the PGIEE does not include own resources of decentralized, autonomous, and social security agencies, nor does it provide complete information on grants.

\footnotetext{
${ }^{52}$ Congress does not approve the budgets of the judiciary nor those of the decentralized and autonomous agencies.
} 
Total public expenditure under the PGIEE excludes the expenditure of decentralized, autonomous, and social security agencies financed with own resources; it only covers constitutional contributions and others ordered under legal mandates. Defense expenditure is fully reported in the budget. ${ }^{53}$ For local governments, it only includes information on national government transfers to them. The Official Gazzette publishes both the budget approved by the Congress of the Republic and the budgets of decentralized and autonomous agencies that by law have to be approved by the executive, but no consolidated public sector budget is put together.

$\underline{\text { Past and forecast fiscal data in the budget }}$

26. The budget document for $\mathbf{2 0 0 5}$ presents fiscal information for three years prior to the budget year and the two subsequent years, although not with the same degree of disaggregation.

The general explanatory statement for the draft 2005 budget (Part II of the Draft) compares the disaggregated budget outturn figures for the central administration in 2002 and 2003, showing the differences in absolute amounts and as a percentage of GDP. It also compares the adjusted 2004 budget and the draft 2005 budget, but at more aggregate levels. In addition, the multiyear budget (Part VI) shows fairly disaggregated fiscal projections for 2005 through 2007, but at a different degree of disaggregation.

\section{Budget treatment of off budget fiscal activity}

27. The budget document does not contain information on contingent liabilities. 2.1 .3 There is no requirement to remit a report on these liabilities together with the budget. Contingent liabilities exist that, if they were called in, could have a major impact on the overall outcome of the public accounts. They include loan securities granted to municipalities and decentralized and autonomous agencies by the government, the fiscal risk associated with the possibility of a bailout (with additional capitalization) for the National Mortgage Bank (CHN), the risk attached to FONTIERRAS' delinquent portfolio, the nonexistence of reserves to pay GUATEL's pension debt or that of the San Carlos de Guatemala University, INFOM's delinquent portfolio, and labor and contractual claims on the state. There is no official estimate of the value of these contingencies, nor enough information available to quantify them. ${ }^{54}$

28. Tax expenditures are considerable and were reported for the first time in the 2004 draft budget documents; quasi-fiscal activities are also considerable, but they are not reported in those documents. Guatemala's tax code includes a large number of tax exemptions. In the budget documents, tax expenditures are estimated at Q 29,537 million

\footnotetext{
${ }^{53}$ There are, nevertheless, reporting restrictions in the defense sector, with respect to the number of those in active service and armament purchased.

${ }^{54}$ The mission obtained the following figures: the debt with national government guarantees amounts to approximately US\$100 million; the CHN's capitalization needs are the equivalent of US\$80 million; and the FONTIERRAS delinquent portfolio totals almost US\$14 million.
} 
(equivalent to 12.7 percent of GDP) for $2005 .{ }^{55}$ The methodology used for the calculation was the static foregone fiscal revenue method and the estimates were made by the SAT. The quasifiscal activities undertaken by some public enterprises (especially INDE) may be important, but they are not reported and the government does not compensate the enterprises for these activities.

\section{$\underline{\text { Publication of data on debt and financial assets }}$}

\section{Complete data are published on central government debt, but they are not} published for the decentralized and autonomous agencies or the municipalities.

Both the MINFIN and BANGUAT publish information on public debt on their websites (www.banguat.gob.gt, and www.transparencia.minfin.gob.gt), and that information is kept up to date. The data provided are gross figures, distinguishing between domestic and external debt and between securitized debt and loans. ${ }^{56}$ Information is also provided on debt service. Debt and deficit data are reconciled. Although the Municipal Code ${ }^{57}$ (Article 115) requires municipalities to submit monthly data to the MINFIN on current domestic and external loans and on the amount of debt outstanding, in practice that obligation is not met. Nor do the decentralized and autonomous agencies provide the MINFIN with information on their operations, despite the requirement to do so contemplated in the LOP. ${ }^{58}$

\section{No information is published on the government's financial assets. No figures are} compiled on the government's equity shares in private enterprises. The MINFIN has no information on the equity shareholdings as such; only on the book value of the shares. That information is not published. The government is a shareholder in EEGSA, EXMIBAL, and BANRURAL; INDE, in turn, owns stock in another enterprise in the electricity sector (ORSUNIL). The stocks of these enterprises are not traded on the stock exchange. Information

\footnotetext{
${ }^{55}$ The figure given in the budget documents is far higher than those obtained in the study by A. Mann and R. Burke, El Gasto Tributario en Guatemala [Tax Expenditure in Guatemala], of March 2002. In that study, using the static foregone tax revenue method, tax expenditure was estimated at 7.3 percent of GDP for 2000; using a simplified form of the overall equilibrium method of the net increase in fiscal revenue (which takes into account changes in economic agents' behavior when tax exemptions are eliminated), the estimate drops to 3.3 percent of GDP. The differences are explained by the fact that the SAT estimates include all the tax exemptions, while the aforementioned study does not take into account exemptions that are considered normal or standard, such as the exemption from income tax for low income individuals.

${ }^{56}$ The external debt is reported by lending institution, debtor, contractual terms, and in dollars (by converting loans denominated in other currencies to U.S. dollar) for the central government. Also reported is the external public debt in which the government of the republic, through the MINFIN, figures as the guarantor. Domestic debt is only partially recorded, as it includes only that contracted by issuing securities (treasury bills and bonds). Domestic debt is reported by instrument and maturity. The reports of securitized public debt project future debt servicing obligations. This is not the case with the external public debt, for which debt servicing projections are calculated but not included in the reports. In all cases, reports are monthly.

${ }^{57}$ Article 115 of the Municipal Code.

${ }^{58}$ Article 62 of the LOP.
} 
on the government's other financial assets (bonds, and so on) is published only annually in aggregate terms as part of the government balance sheet.

\section{Open Budget Preparation, Execution, and Reporting}

The budget preparation process: clarity and consistency of the process and presentation

\section{The budget process is transparent and its presentation is consistent with} international standards, although it excludes the autonomous and decentralized agencies and the legislative and judicial branches from the budget debate

The executive issues budget policies and general guidelines based on the BANGUAT's estimate of macroeconomic trends. ${ }^{59}$ Based on those policies and guidelines, the institutions prepare their preliminary draft budget and present it to the MINFIN by June 15 of each year. According to Article 183.j of the Constitution and Article 23 of the LOP, the executive branch, via the MINFIN, must submit the draft budget to congress no fewer than 120 days prior to the start of the fiscal year (that is to say, by September 2 of each year). Congress has to approve, amend, or reject the draft by no later that 30 days before the start of the following fiscal year (by November 30). The decentralized agencies submit their draft budgets for approval by the executive by December 15 of each year, while the autonomous agencies approve their own budgets and submit them each year to the executive and to congress for their information and incorporation. The budgets use the following classifications: by institution, by expenditure item; by economic classification, by purposes and functions, by sources of financing; and by geographical location. The economic classification is consistent with the 1986 edition of the IMF's GFSM. Although the classification by functions is adequate, the Budget does not classify some expenditures appropriately. ${ }^{60}$

Investments are not adequately prioritized and there is no close coordination between current expenditure and investment budgeting. The investment projects included in the budget must be registered in the National Public Investment System (SNIP) and submitted

\footnotetext{
${ }^{59}$ To prepare the 2005 budget, the MINFIN and the Secretariat of Planning and Programming of the Presidency (SEGEPLAN), sent institutions three documents (see Table 2). The first, prepared jointly with SEGEPLAN and entitled "Strategy for Formulating the Draft General State Revenue and Expenditure Budget," was sent out in February 2004. The document describes the general objectives underlying the budget formulation process, the legal bases for that process, and the standards to be considered by the executing units when drawing up their Annual Work Plans and their preliminary draft budgets, and it establishes the timetable of activities. In February, SEGEPLAN, which is responsible for coordinating the public investment planning and programming process, produces a document entitled "Guidelines and Instructions for Proposing Investment Projects." It sets the deadline for submission of projects for technical, economic, and social evaluation (April 15) and their incorporation in the National Public Investment System (SNIP) and in the Public Investment Program (PIP). The third document is called "Standards for Formulating the Draft General State Revenue and Expenditure Budget" and is sent out in May by MINFIN. It describes the country's recent economic and fiscal performance and establishes government policy guidelines and expenditure priorities. It also includes the budget rules to be followed by the different executing units and decentralized and autonomous agencies when drawing up their respective draft budgets.

${ }^{60}$ Some programs, such as pre-school education or physical education are not broken down sufficiently and hence not adequately classified in activities that allow them to be measured. Also, the external loans administered by one specific executing unit are not charged to the programs on the basis of final use of the funds.
} 
Table 2. Budget Calendar

\begin{tabular}{|c|c|c|c|c|c|c|c|c|c|c|c|c|}
\hline & $\mathrm{J}$ & $\mathrm{F}$ & M & A & $\mathrm{M}$ & $\mathrm{J}$ & $\mathrm{J}$ & A & $\mathrm{S}$ & $\mathrm{O}$ & $\mathrm{N}$ & $\mathrm{D}$ \\
\hline \multicolumn{13}{|l|}{ General Revenue and Expenditure Budget } \\
\hline \multicolumn{13}{|l|}{ Executive Branch } \\
\hline Determination of Macroeconomic Assumptions & & $\mathbf{x}$ & $\mathbf{x}$ & & & & & & & & & \\
\hline Preparation of Draft Budget Formulation Strategy (Art. 20 LOP) & & $\mathbf{x}$ & $\mathbf{x}$ & & & & & & & & & \\
\hline Preparation of Standards to Govern Draft Formulation (Art. 20 LOP) & & $\mathbf{x}$ & $\mathbf{x}$ & & & & & & & & & \\
\hline Preparation of Investment Guidelines by SEGEPLAN (Art. 20 LOP) & & $\mathbf{x}$ & $\mathbf{x}$ & & & & & & & & & \\
\hline Delivery of Strategy, Standards, and Guidelines & & & & $\mathbf{x}$ & $\mathbf{x}$ & & & & & & & \\
\hline Revenue Projection (SAT and the MINFIN) & & & & $\mathbf{x}$ & $\mathbf{x}$ & & & & & & & \\
\hline Preparation of Public Investment Strategy & & & & & $\mathbf{x}$ & & & & & & & \\
\hline Review, Analysis and Adjustment of Budget Ceilings & & & & & $\mathbf{x}$ & & & & & & & \\
\hline Approval of Budget Ceilings by the Council of Ministers & & & & & $\mathbf{x}$ & & & & & & & \\
\hline Delivery of Annual Work Plans & & & & & $\mathbf{x}$ & & & & & & & \\
\hline Delivery of Preliminary Drafts by the institutions (Art. 16 RLOP) & & & & & & $\mathbf{x}$ & & & & & & \\
\hline Analysis and Discussion of the Preliminary Drafts & & & & & & $\mathbf{x}$ & $\mathbf{x}$ & & & & & \\
\hline First draft of the Draft General Budget & & & & & & & & $\mathbf{x}$ & & & & \\
\hline Approval of the Draft Budget by the Council of Ministers & & & & & & & & $\mathbf{x}$ & $\mathbf{X}$ & & & \\
\hline Presentation of the Draft Budget to Congress (Art. 171 CPE) & & & & & & & & & $\mathbf{x}$ & & & \\
\hline Legislative Branch & & & & & & & & & & & & \\
\hline Analysis of the Draft Budget & & & & & & & & & $\mathbf{X}$ & $\mathbf{x}$ & $\mathbf{x}$ & \\
\hline Approval (Art. $171 \mathrm{CPE})$ & & & & & & & & & & & $\mathbf{x}$ & \\
\hline Budgets of the Autonomous (A.A.) and Decentralized Agencies (D.A & & & & & & & & & & & & \\
\hline Presentation to the Ministry of Finance of A.A. and D.A. Budgets & & & & & & & & $\mathbf{x}$ & $\mathbf{x}$ & $\mathbf{x}$ & $\mathbf{x}$ & $\mathbf{x}$ \\
\hline Approval by the Executive of D.A. Budgets (Art. 40 LOP) & & & & & & & & & & & & $\mathbf{x}$ \\
\hline
\end{tabular}

to an evaluation by SEGEPLAN if they are to be included in the Public Investment Program (PIP). ${ }^{61}$ Nevertheless, SEGEPLAN does not evaluate all the projects it receives. ${ }^{62}$ Moreover, the SNIP does not include projects developed by the funds, or by the decentralized and autonomous agencies, or international cooperation projects, whose value greatly exceeds that of the projects registered in the SNIP. The PIP may also be radically altered by congress, which can modify the government's priorities. The annual work plans (POA) are a mere formality, because they are not based on strategic planning by the institutions. There is no proper coordination between the MINFIN and SEGEPLAN aimed at foreseeing the implications for current (operating and maintenance) expenditure of new investments and investments already under way.

\footnotetext{
${ }^{61}$ According to Decrees 101-97 and 114-97 of the Congress of the Republic, SEGEPLAN must prepare the PIP for a four-year period.

${ }^{62}$ Sector projects that are not externally financed are sent to SEGEPLAN with an already completed evaluation; in the case of externally-financed projects, SEGEPLAN has 15 days to issue an opinion.
} 
The macroeconomic framework and policy basis for the budget

\section{The general government's fiscal balance is not the principal indicator of the fiscal} position in the budget. The key indicator for formulating fiscal policy is the central government's ${ }^{63}$ fiscal balance, an indicator that is monitored throughout the year. The central government's primary balance and current balance are also periodically calculated. No fiscal information is produced on the autonomous and decentralized agencies, or for the municipalities.

\section{There is little opportunity to discuss macroeconomic and fiscal models and} assumptions.

Budget forecasts and macroeconomic assumptions are clearly set out in the budget documents, but the models used to estimate both are merely described, without any quantitative information regarding the parameters. The budget preamble (Part II) provides an analysis of recent economic outlook scenarios and brief explanations of how the macroeconomic projections used were generated. These projections are provided by BANGUAT, but the bank does not publish information on the methodologies used to prepare them. Part VI of the draft law (multiyear budget) does mention the independent variables used to make fiscal projections, but no quantitative data are provided on the parameters for the models. That means that the information provided is insufficient to form an opinion regarding the technical quality of fiscal forecasts. Nevertheless, they have generally been close to actual outcomes.

$\underline{\text { Medium-term planning and analysis of fiscal risks }}$

35. The budget document does not include a statement of the medium-term fiscal policy objectives, nor are there any analyses of fiscal sustainability. Also, there is no assessment made of the sensitivity of budget estimates to changes in the macroeconomic variables.

Since 2003, a multiyear budget has been included in the budget documents presented to congress. The 2005 budget included (in Part VI of the draft) an exercise for the 2005-07 period, which includes the possible effects on revenue of administrative changes in the SAT and in tax and foreign trade policies, as well as the possible effects of new investments on recurrent operating and maintenance expenditure. It is not, however, based on a definition of explicit and numerical medium-term fiscal policy objectives. Fiscal objectives are defined generically, as maintenance of capital expenditure and public debt levels compatible with the commitments of the Fiscal Pact, which are not spelled out in the multiyear programming exercise. Nor are medium-term sector objectives spelled out. For that reason, the exercise cannot yet be used as a reference point for the annual budget process. Nor does it contribute to the evaluation of fiscal sustainability, because almost all components of expenditure were projected on the basis of availability of current revenue. Furthermore, the exercise does not include a sensitivity analysis of the impact of changes in the macroeconomic variables and other fiscal risks on government finance in the short and medium term. For preparation of the

${ }^{63}$ Excluding decentralized and autonomous agencies. 
draft 2006 budget, changes were introduced so that public entities would undertake their multiyear expenditure programming (2006-08) in a manner consistent with their medium-term objectives; it is hoped that this will remedy these weaknesses.

36. Numerical fiscal rules are not applied in the budget process. 3.1 .2

The only fiscal rule established by law states that debt may only be contracted to finance investment expenditure. Other fiscal rules taken as a benchmark in some years are derived from the Peace Agreements and the Fiscal Pact, which establish that social expenditure must be an increasing percentage of total expenditure, that tax effort must be 12 percent of GDP, and that public investment must be kept at a minimum of 4 percent of GDP. However, application of these last rules is discretionary and depends on the political will of the government concerned.

\section{The budget documents do not distinguish between the costs of programs under} way and the costs of new expenditure proposals.

Although the Explanatory Statement of the draft 2005 General Budget mentions and describes the new programs and projects, their respective costs are not clearly distinguished from those of the programs underway.

\section{Clarity of control of budget execution}

\section{Budget laws establish accounting procedures and the ground rules for internal} controls, but in practice the rules are not adequately applied.

In the central government sphere, accounting is done through the Integrated Accounting System $^{64}$ (SICOIN), which guarantees the internal consistency of the entries. The LOP ${ }^{65}$ requires the whole public sector to record budget execution at the commitment, accrual, and payment stages, and its regulations ${ }^{66}$ clearly define what is meant by commitment and accrual. In actual practice, the fact that controls are only exercised over the payments stage (the MINFIN establishes maximum monthly expenditure quotas for each institution) has meant that the institutions habitually record commitment and accrual at the same time. This means that, legally speaking, the accrual accounting system ends up operating with cash basis criteria, which is why major payments arrears in recent years are not reflected in the accounts (because accruals are registered when a payment authorization is issued). ${ }^{67}$

\footnotetext{
${ }^{64}$ SICOIN is the information system of SIAF. It comprises four modules: budget, accounting, treasury, and public credit.

${ }^{65}$ Article 16 of the Organic Budget Law.

${ }^{66}$ Article 12 of the Organic Budget Law regulations.

${ }^{67}$ According to the Budget Execution Programming Manual, the payment quota approved for an agency shall be the maximum accrual amount. Consequently, commitments may be entered into for that amount. This has meant that, regardless of when an obligation accrues, the institutions always record both phases of expenditure simultaneously. Thus, if one examines SIAF accounting entries, one sees that accruals and payments are identical and that therefore, by definition, there is no floating debt, which does not means to say that there are no payment arrears. In reality, arrears are not recorded in the system, essentially because the commitment is not recorded at the proper time.
} 
39. Financial management is not adequately coordinated.

3.3.1, 2.1.4

Implementation of SIAF has improved public financial administration, including the budget, accounting, and treasury subsystems. However, its coverage is still incomplete, as it comprises 22 out of 37 decentralized and autonomous agencies. In addition, there is still not adequate system for managing the public debt (a risk management system), be it short, medium or long term. There is no TSA; due to legal restrictions, the treasury account in BANGUAT does not include the resources of the decentralized and autonomous agencies, nor those of the trusts established by the state in financial institutions. This prevents efficient management of liquidity.

40. The internal control system is adequately regulated, but is not fully effective. 3.3 .3 The $\mathrm{LOP}^{68}$ makes the highest authority in each public sector institution responsible for introducing and maintaining an internal control system in line with the general standards established by the CGC. Each organization has to have an internal audit unit (UDAI) ${ }^{69}$ to evaluate operations and their outcomes, after execution. Inter alia, it is supposed to check the structure of existing internal controls, the reliability and completeness of the information, compliance with standards, the safekeeping of assets, the economic and efficient use of resources, and compliance with the objectives established for the organization. The UDAIs prepare an annual audit schedule which, following approval by the highest authority in the institution, is sent to the external control body for its information and for coordination purposes. Their reports are forwarded to the highest authority of the audited entity, and copied to the heads of the area inspected and to the CGC. They are not, however, made public. Although these units have now been established in almost all institutions, some are not yet acting with the required effectiveness, judging by the reports of the CGC. Moreover, in practice, the controls established have proved to be insufficient. In the past this meant that expenditure was effected that did not meet the legal requirements and was incorrectly recorded in the books. Furthermore, the units' dependence on the highest authority in the institution limits their autonomy.

\section{Public procurement rules are clear and well known. Recently, they underwent} major changes that increased transparency.

Some recent changes to the rules are intended to increase the transparency of procurement via competitive bidding, although there are still areas exempt from publicity and competition requirements. The Law on Government Contracting ${ }^{70}$ applies to government agencies, the decentralized and autonomous institutions, executing units, municipalities and state and municipal public enterprises. The law regulates four contracting systems: public bidding, ${ }^{71}$ which applies to contracts worth over Q 900,000 and which requires publication of the invitation to bid in the Official Gazzette and another large circulation newspaper; price

\footnotetext{
${ }^{68}$ Article 1 of the Organic Budget Law.

${ }^{69}$ Article 24 of the Executive Branch Law.

${ }^{70}$ Article 1 of Decree 57-92 of the Law on Government Contracting.

${ }^{71}$ Article 17 of the Law on Government Contracting.
} 
quotation, ${ }^{72}$ which applies to contracts worth less than that but more than Q 10,000, and which requires that there be at least three pro forma; direct purchase, ${ }^{73}$ for contracts worth less than Q 10,000; and the open contract system, ${ }^{74}$ which allows government agencies and dependencies to purchase goods and supplies without a bidding or price quotation process directly from suppliers that have signed open contracts with the ministry of public finance, after having been qualified as a supplier and following price comparisons and adjudication. The existence of four different systems depending on the value of the contract encourages fragmentation of the larger contracts. The law provides for the establishment of a Register of Contracts ${ }^{75}$ in the CGC, which is still pending. Government Resolution 80-2004 amended Article 8 of the regulations of the Government Procurement and Contracting Law, to make all the institutions subject to this law, prior to the procedure defined in the law and its regulations, publish and arrange in the information system for managing and recording public contracts (GUATECOMPRAS) the notices and invitations to bid and all the information related to the purchase, sale, and contracting of goods, supplies, works, and services they need to make by means of bids, price quotations, or other types of competition; and it ordered said information to be made public through the Internet website www.guatecompras.gt. This makes it possible to monitor the government's competitive procurement processes. The system also enables government suppliers to ascertain the status of payments pending.

\section{The law provides for important exceptions to the obligation to use bidding and} price quotation systems. The Law on Contracting is not applied in some enterprises and institutions, by virtue of the laws that created them, which established their own contracting systems. Furthermore, Article 44 of the Law establishes exceptions to the obligation to use bidding and price quotation, including such grounds as the need to safeguard borders or territorial integrity, states of emergency, goods or services for dependencies abroad, arms purchases, purchases of real estate, and the provision of individual professional services, and other cases; and exemptions from bidding, but not from price quotations, for studies, designs, and supervision of technical works and services; scientific, artistic, or literary works; electoral campaign events, and so on.

\section{The civil service system is fragmented and governed by ambiguous rules that} permit discretionary decisions with respect to hiring, remuneration, and promotion. ${ }^{\mathbf{7 6}} 3.3 .2$ Article 108 of the Constitution establishes that relations of the state and its decentralized and autonomous agencies with their employees will be governed by the Law on the Civil Service, ${ }^{77}$

\footnotetext{
${ }^{72}$ Article 38 of the Law on Government Contracting.

${ }^{73}$ Article 43 of the Law on Government Contracting.

${ }^{74}$ Article 46 of the Law on Government Contracting.

${ }^{75}$ Article 74 of the Law on Government Contracting.

${ }^{76}$ This paragraph is based on: IDC, "Institutional Diagnosis of the Civil Service System in Guatemala," InterAmerican Development Bank, November 2002.

${ }^{77}$ Decree 1748 of May 2, 1968, approving the Law on the Civil Service and its regulations. The Labor Code also applies, on a supplemental basis.
} 
with the exception of those agencies governed by special laws and provisions. A large number of institutions have their own civil service laws; ${ }^{78}$ and in some institutions governed by the Civil Service Law some groups are exempt ${ }^{79}$ while in others the rules governing appointments do not apply. ${ }^{80}$ Moreover, subsequent rules and regulations have been adopted that even go beyond the scope of the Framework Law and contradict it. Consequently, there is a heterogeneous and contradictory human resource management regime. Hiring requirements are usually not publicly disclosed and, although they are regulated by law, selection procedures leave much to the discretion of the contracting party. ${ }^{81} \mathrm{~A}$ large number of public institutions do not have job profiles or lists of requisites for specific posts. The law allows for exams to be held without the need for the candidate to be present, at which his or her skills are assessed on the basis of the documents provided. The exams conducted are of a general nature and not related to the specific nature of the position to be filled. A compensation system dominated by seniority and discretionary criteria, the lack of performance evaluations, and a wage increase policy designed to give more to lower levels ${ }^{82}$ have eliminated incentives for good performance and promotion; ${ }^{83}$ and the prior notice requirement has been used to ensure job stability. Management of the civil service is split as follows: the national civil service office (ONSEC) is responsible for seeing that the law is enforced, while the national civil service board serves, among other things, to promote improvements in the system and to investigate and settle claims related to management of public sector staff. There is no one source in the government that can say how many government employees there are at any given time; the available figures refer to authorized posts, not to those that are actually filled, and they do not include all categories of employees. ${ }^{84}$ The Public Servants Information System is incomplete and unreliable; and, therefore, not in a position to avoid dual jobs, illegal appointments, or appointments of disqualified persons. The authorities are preparing a draft law that will reform the current system.

\footnotetext{
${ }^{78}$ These include the legislature and the judiciary, the Court of Constitutionality, the Offices of the Attorney General and of the Government Attorney for Human Rights, the CGC, the Ministry of Defense, the Supreme Electoral Tribunal, approximately 21 decentralized agencies, and the municipalities.

${ }^{79}$ This is the case for embassy and consular personnel, for instance, as well as the personnel in the National Police directorates and the prison system.

${ }^{80}$ This is the case for decentralized agencies forming part of the Civil Service.

${ }^{81}$ Experience with hiring military personnel in the SAT during the previous government illustrates this discretionality problem.

${ }^{82}$ Furthermore, the civil service post assessment system has not been applied since 1989. This has resulted in salary differentials of between 100 and 200 percent for similar category jobs, depending on whether they are in exempted services or part of the Civil Service.

${ }^{83}$ There are no mechanisms to provide accreditation for training received or to obtain the corresponding incentives.

${ }^{84}$ The National Office of the Civil Service (ONSEC) indicated 172,895 positions for the central government and 2,665 for the decentralized entities administered by it.
} 
Clarity of internal controls and independence of the tax administration

\section{The tax administration authority is subject to effective monitoring and internal control mechanisms.

The SAT has an internal audit directorate, responsible for supervising and auditing its activities. Its objective is to verify that management procedures are carried out in accordance with the Organic Law of the SAT, internal rules, and technical administrative manuals. This directorate reports directly to the superintendent, and performs its duties with the help of an internal audit subdirectorate and financial and operational audit and information systems and research audit departments.

45. The Tax Authority is not legally protected from political interference.

Although the SAT was granted the legal status of a decentralized agency, its staff were professionally trained, and it was assigned specially earmarked funds ( 2 percent of all the revenue it collects), it proved impossible to include a rule guaranteeing job stability for the Superintendent. According to Article 27 of the Organic Law of the SAT (Decree No. 1-98), grounds for dismissing the superintendent include acts contrary to the best interests of the SAT, negligence in the performance of his or her duties, and failure to achieve the collection targets established in annual agreements with the executive. There have been three superintendents between 2001 and 2003, and in 2003 the SAT was involved with incidents of corruption.

Accounting and reporting of budget execution

46. The SICOIN is capable of producing accurate and thorough intra-annual reports on central government budget execution (excluding some decentralized and autonomous agencies).

SICOIN is able to generate immediate budget execution reports. The decentralized and autonomous agencies that work with SICOIN can likewise report their budget outturn. The SICOIN is consistent and integrated into the budget classification. Financial statements are linked to the budget accounts through conversion matrices that perform accounting entries automatically when expenditure is executed (accrued and paid). SIAF defines the phases of expenditure (commitment, accrual, payment) as required by current regulations and can provide this disaggregated information by revenue category and expenditure category.

\section{By law, congress receives periodic reports on budget execution, but it does not} debate them.

Under Article 183.w of the Constitution, the President of the Republic has to send congress, every four months, the analytical report on budget execution. Moreover, in February of each year, each ministry has to deliver a report on its activities and budget execution. The decentralized and autonomous agencies report their budget execution every four months and their budget outturn and financial statements have to be sent to congress by March 31 of each year, with a copy to the MINFIN. There is no obligation to publish these reports. Nevertheless, the MINFIN publishes central government budget execution information on its website. The legislative branch does not discuss these reports. 
48. Audited accounts are available within five months after the end of the fiscal year.

3.4 .2

In accordance with the Constitution, the MINFIN prepares the PGIEE outturn and the closing of the fiscal year accounts within the first three months of each year and sends it to the CGC. The latter issues an opinion within two months, which it sends to congress for approval; or rejection. Once the outturn has been approved, a summary of the government's financial statements is published in the Official Gazzette. The decentralized and autonomous agencies have the same obligations.

$\underline{\text { Results-oriented budgeting and reporting }}$

49. A performance-based budgeting approach was introduced with the preparation of the 2006 budget.

The budget preparation rules and system were amended to include the definition of strategic institutional objectives, operational objectives, and targets for the various expenditure programs of each institution. In this way, financial inputs (executed expenditure) can be linked with output indicators (goods and services). This will increase accountability and in the long-run can increase effectiveness and efficiency of government programs.

\section{Assurances of Integrity}

$\underline{\text { Integrity of data processes }}$

50. The budget sent by the Executive Branch to the Legislative Branch for approval is not a reliable indicator of actually observed revenue and expenditure. The powers of both congress and the executive to amend the budget, which are used extensively, mean that the approved budget cannot be taken as a good indicator of fiscal policy.

51. The differences between budgeted amounts and the budget outturn results are disclosed to the public and the legislature. The reports on execution of the PGIEE and the fiscal transparency portal provide information comparing the approved budget with the amended budget and execution. The SICOIN budget execution reports also provide this information. The budget amendments approved by congress are published in the Official Gazette and on congress's website. In addition, since 2004 the MINFIN website has included information on interinstitutional budgetary transfers approved by the executive branch through which the allocation of resources to agencies is amended. However, the budget documents do not provide information on the previous years comparing the budget submitted with the one approved and with the outturn. They only provide information on expenditure carried out.

52. Accounting policy statements are not included in either the budgets or their outturns, because SIAF's accounting standards are public. $\quad$ 4.1.2 SIAF has an accrual accounting system. This is only used by the institutions that form part of SIAF, that is to say, the executive branch and some decentralized and autonomous agencies. The remaining institutions still have the accounting system in effect prior to the establishment of SIAF, which uses different accounting principles and standards. 
53. The accounts reconciliation and fiscal reporting processes do not cover the entire central government.

Budgetary and accounting data are reconciled automatically every day through SIAF. However, reconciliation of fiscal data with the monetary accounts is restricted exclusively to the "common fund" (the treasury account), and does not cover the resources of the autonomous and decentralized agencies.

\section{$\underline{\text { Independent oversight }}$}

\section{The external audit is independent of the Executive Branch and its mandate covers all public sector activities.

Under the constitution, the CGC is an independent, technical, and decentralized institution. It approves its own budget. The procedure for selecting the comptroller is based on a collegial system and conducted through an applications committee, ${ }^{85}$ which submits six candidates to congress, so that congress can elect the comptroller by an absolute majority. The collegial procedure is intended to depoliticize the position, but it is not transparent; nor does it guarantee the election of the most suitable person. ${ }^{86}$ The comptroller may be dismissed only by congress and for negligence, committing a crime, or because of unsuitability, and under no circumstances may be re-elected. The CGC has jurisdiction over the whole of the public sector and over any person, entity, or institution receiving state funds. The Organic Law of the CGC (Decree No. 31-2002) replaced the previous law, which dated back to the 1950s and which emphasized accounting audits of all the supporting documentation and assigned it other functions: audits of the assets, liabilities, revenue, and expenditure of the public sector; determining whether the management of the entities it audits is conducted in accordance with the criteria of honesty, effectiveness, transparency, economy, and fairness; safeguarding the transparency and honesty of public administration; and promoting the modernization of the government's internal audits. The comptroller must report on his activities to congress whenever so required and ex officio, twice a year.

55. The CGC has only limited capacity to conduct external audits. The CGC has a staff of approximately 700 people, 180 of whom have degrees. The office therefore lacks appropriate human resources to perform its functions. In practice, audit

\footnotetext{
${ }^{85}$ Composed of representatives of the Dean of the Economics Faculty, rectors of the country's universities, and the Economic Sciences College, etc.

${ }^{86}$ When the comptroller was elected in 2002, a civil society organization called "Coalition for Transparency" took part in the process, in an attempt to ensure transparency and the election of the candidate with the best technical, managerial, and ethical qualification and the best work plan. In its evaluation of the process, this organization concluded that the composition of the Applications Committee was inappropriate, as is the mechanism for selecting representatives of the Economic Sciences College. It added that the process by which the committee selected candidates was not transparent and that the qualification criteria proposed by the Coalition to ensure the suitability of the candidates and enhance the objectivity of the procedure had no impact on the final decision. Coalición por la Transparencia, 2003, Rindiendo Cuentas; El proceso de elección del Contralor General de Cuentas de la Nación. Resumen del proceso y sugerencias para mejorarlo [Coalition for Transparency, 2003, A Report. The Procedure for Electing the Comptroller General of the Accounts of the Nation. Summary of the process and suggestions for Improving it], December.
} 
coverage is partial and major institutions go without in-depth audits for several years. The CGC has only limited capacity to use SIAF in a productive manner, or to conduct investigations into activities associated with illicit enrichment. The audit findings are published, but not in detail, and there is no strict monitoring of recommendations. Fines are imposed for breaches of current regulations, but nobody knows to what extent lost public funds are recovered. Introduction of the SIAF-SAG information system will result in greater audit efficiency, but this will also depend on improvements in the technical capacity of the staff of the CGC.

56. The Legislature does not debate external audit reports in depth.

The CGC issues an opinion and report on the financial statements, execution, and outturn of the PGIEE and of the autonomous and decentralized agencies and send them to the legislature within 150 days of the close of the fiscal year. congress may approve or reject the outturns. The legislative branch does not discuss the opinions in depth.

\section{Although the law grants technical independence to the National Institute of} Statistics (INE), that independence is not guaranteed; and the Institute's capacity is very limited.

According to the Organic Law of the INE, the government grants it the independence it needs to meet its objectives, especially in technical areas. Nevertheless, its lack of financial autonomy and the fact that it is governed by a board of directors composed of representatives of the ministries and manufacturing associations may impair its autonomy. INE does not compile fiscal statistics, as this is done by the MINFIN; nor does it compile the National Accounts, as this is currently done by BANGUAT. Nor does the Institute compile monthly output figures. One of the few products delivered by INE on a periodic basis is its report on inflation. The human and physical resources at INE's disposal are insufficient, even to produce the inflation index.

\section{COMMENTS BY IMF STAFF}

\section{Guatemala has progressed in certain important aspects of fiscal transparency:}

- $\quad$ Recent regulatory changes (the Municipal Code, the Organic Law of the BANGUAT, a series of laws related to financial activities, and the law governing the CGC) have clarified intergovernmental fiscal relations and those between the government and the central bank. They have also strengthened banking supervision and the capital of financial institutions, thereby reducing the risk of fiscal contingencies, and they have promoted strengthening of the CGC.

- The preparation of multiyear budgets - which can still be improved and which were linked for the first time to the annual budget process in the preparation of the $2006 \mathrm{draft}$ budget - also constitutes an important and necessary first step for enhancing the quality of the annual budgets.

- $\quad$ Rigorous estimates of tax expenditures have been made and the information in that regard is made available to the public in the web pages of MINFIN and SAT. 
- A well defined accounting system exists, with principles and standards, which, if they are strictly adhered to, would make it possible to produce timely and reliable fiscal reports.

- $\quad$ The adoption of the SIAF by all institutions in the executive branch and more than half the decentralized and autonomous agencies has made it possible to modernize budget, treasury, and accounting procedures, improve management and control of public funds, and prepare timely budget execution reports.

- $\quad$ The adoption of SIAF-MUNI by 36 municipalities in 2004 and almost 100 in 2005 (which will allow for implementation of integrated municipal financial management), and the use of SIAFITO-MUNI (through which budget execution by the municipalities is reported) in almost all municipalities, will improve resource management at the local level and the monitoring of their finances by the national government.

- $\quad$ The development of the SAG by the CGC will facilitate external audits.

- $\quad$ The obligatory adoption of the GUATECOMPRAS by much of the public sector will afford greater transparency in contracting processes.

- The annual budget and the MINFIN website provide increasingly complete information on central government activities (executive branch), including information on tax expenditures and debt, and multiyear budget scenarios.

59. However, Guatemala still does not meet the core requirements of the Code on fiscal transparency in several areas. In order of priority, these requirements are:

- $\quad$ Adopt a definition of government that conforms to international standards and broaden budget and reporting coverage in line with that new definition. Maintaining the current institutional structure of the public sector, the general government sector would consist of central government (which corresponds to what the Manual on Budget Classifications now calls "Central Administration") and the local governments. The central government would consist of the central administration (which is nowadays referred to as "central government") and the decentralized agencies (which include the decentralized nonbusiness agencies, the autonomous nonbusiness agencies, and the social security institutions).

- In keeping with the new definition, the PGIEE should cover all fiscal activity of the central government, and the budget documents should show a consolidation of all the institutional budgets of the central government. The periodic budget execution reports should have the same coverage as the PGIEE. It is hoped that implementation of SIAF in all decentralized and autonomous agencies will permit this consolidation.

- Improve accounting practices, recording the different states of expenditurecommitment, accrual, payment — as and when they occur, so that the floating debt can be calculated. 
- Increase and improve the contents of budget documentation, providing more complete information on the fiscal activity of the government and the consolidated public sector, identifying, quantifying, and reporting contingencies and quasi-fiscal activities, and reporting information on the parameters and assumptions used in the macrofiscal models utilized in preparing the budget. A complete report should be produced on fiscal risks, analysis of fiscal sustainability, and a statement on the objectives of medium-term fiscal policy.

- $\quad$ Improve the quality of the multiyear budgeting exercise. Regarding performance-based budgeting, the authorities must continue to fine-tune the changes introduced into the budget preparation rules and system for 2006 .

- $\quad$ Clarify the separation of functions and responsibilities between the executive and legislative branches in connection with the budget. It would be necessary to clearly define and demarcate the powers of the Congress of the Republic to amend budgets, since they disturb the whole process of preparing and executing the budget and they prevent a clear assignment of responsibilities for fiscal matters. That is a prerequisite for producing more realistic budgets; an unrealistic budget does not adequately convey government priorities.

- Gradually reduce the use of social funds and trusts for resource management, as they detract from transparency in the budget process and prevent the efficient management of liquidity.

- Distinguish clearly the specific spheres of competence of the central government, the development councils, and the municipalities regarding public investment selection.

- $\quad$ Strengthen external controls by enhanced training in the use of information systems and by stricter monitoring of audit recommendations.

- In order to increase transparency in government contracting, reduce the number of activities and entities that are exempt from application of the law on contracting and the use of GUATECOMPRAS.

- Submit to congress the new draft civil service law, to replace the regulations in force since 1968, and establish transparent selection and compensation criteria for civil servants, based on merit and capacity.

- $\quad$ Consolidate and strengthen the national public investment system and strengthen coordination among the entities responsible for formulating current and capital expenditure budgets. It is necessary to build a SNIP with complete coverage, and containing medium-term information, so that they can serve as supporting material for the multiyear budget. The institutions' strategic planning exercises also need to improve. 
- It should be also a top priority to protect the superintendency of tax administration from political interference, grant job stability to the principal executives, as has been done in other important state institutions, and specify more precise grounds for dismissal.

- Improve monitoring of subnational governments' finances and produce reports on the consolidated general government. To that end, mechanisms should be established to enforce municipal debt authorization and reporting obligations, using the legal instruments afforded by the municipal code, and information gathered through SIAFMUNI and SIAFITO-MUNI, and information on budget execution of the local governments, and consolidate it with that of the central government.

- It is necessary to establish clear and consistent criteria for assigning transfers to municipalities (they should be based on needs and tax capacity) and to disclose the information used to calculate them as well as the results obtained.

Legal changes are needed for the implementation of various of these recommendations, and some even require constitutional amendments. However, many only require changes to the fiscal management processes. 







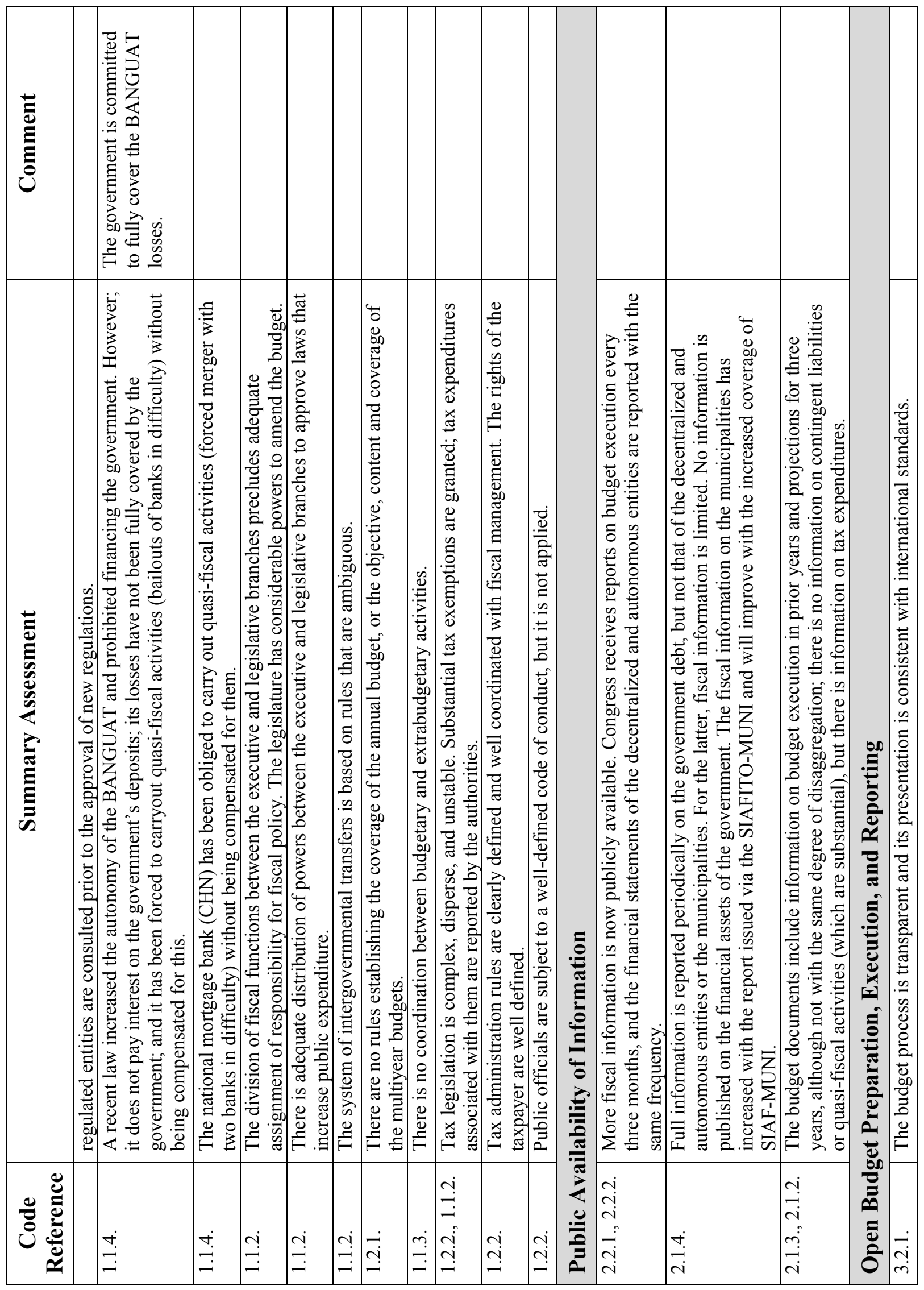




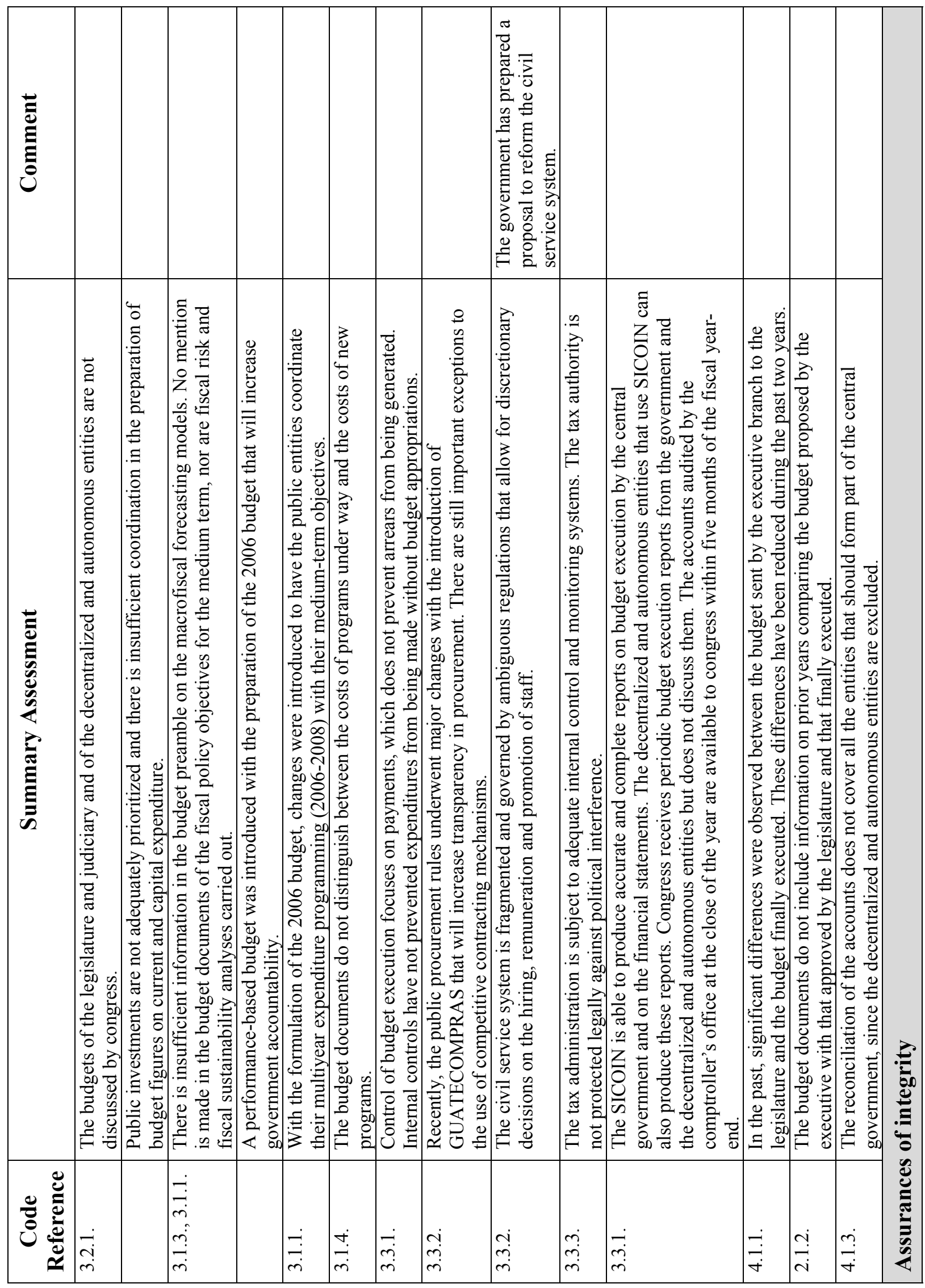




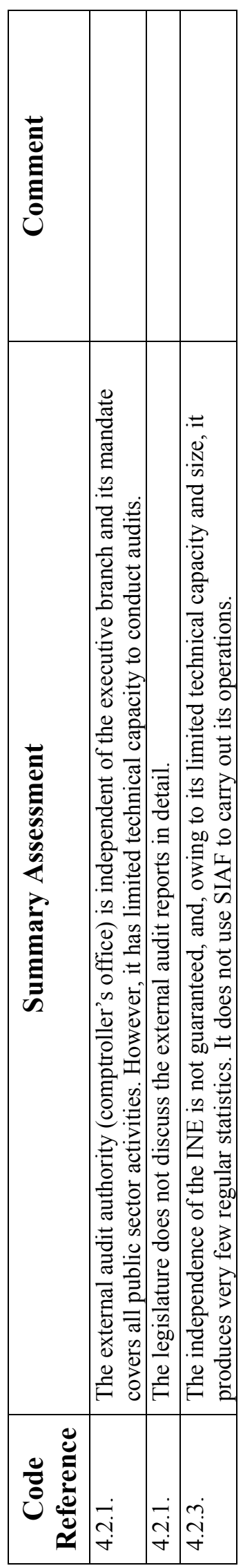




\section{Public Availability of Information-A Summary}

\begin{tabular}{|c|c|c|c|c|c|}
\hline & Budget or Fiscal Report & $\begin{array}{c}\text { Included in the Budget } \\
\text { or in Reports }\end{array}$ & $\begin{array}{c}\text { Available to the } \\
\text { Public }\end{array}$ & $\begin{array}{l}\text { Paragraph } \\
\text { Referred to }\end{array}$ & $\begin{array}{l}\text { Reference } \\
\text { Code }\end{array}$ \\
\hline 1. & $\begin{array}{l}\text { Budget forecasts, central } \\
\text { government (CG) }\end{array}$ & Yes & $\begin{array}{l}\text { Official Gazzette } \\
\text { and MINFIN } \\
\text { website }\end{array}$ & Paragraph 24 & 2.1 .1 \\
\hline 2. & Defense expenditure (CG) & Yes & Yes & Paragraphs 25 & 2.1 .1 \\
\hline 3. & $\begin{array}{l}\text { Extrabudgetary funds of } \\
\text { the CG (including special } \\
\text { development funds, social } \\
\text { security funds and } \\
\text { earmarked revenues) }\end{array}$ & $\begin{array}{l}\text { No } \\
\text { There are extrabudgetary } \\
\text { funds not included in the } \\
\text { budget: own income or } \\
\text { revenue prerogatives of } \\
\text { decentralized or } \\
\text { autonomous agencies and } \\
\text { the Judiciary }\end{array}$ & $\begin{array}{l}\text { Yes } \\
\text { Budget of } \\
\text { decentralized and } \\
\text { autonomous } \\
\text { agencies is } \\
\text { published in the } \\
\text { Official Gazzette }\end{array}$ & $\begin{array}{l}\text { Paragraphs } 3, \\
25, \text { and } 31\end{array}$ & 2.1 .1 \\
\hline 4. & Budget outturn of the CG & $\begin{array}{l}\text { Yes } \\
\text { Budget Preamble Part II } \\
\text { Relatively aggregated } \\
3 \text { prior years }\end{array}$ & $\begin{array}{l}\text { Yes } \\
\text { Budget Preamble } \\
\text { Part II }\end{array}$ & Paragraph 26 & 2.1 .2 \\
\hline 5. & CG budget forecasts & $\begin{array}{l}\text { Yes } \\
\text { Part VI, Draft PGIEE } \\
\text { Relatively aggregated } 3 \\
\text { subsequent years }\end{array}$ & $\begin{array}{l}\text { Yes } \\
\text { Part VI Draft } \\
\text { PGIEE }\end{array}$ & Paragraph 26 & 2.1 .2 \\
\hline 6. & $\begin{array}{l}\text { Contingent liabilities of the } \\
\text { CG }\end{array}$ & No & No & Paragraph 27 & 2.1 .3 \\
\hline 7. & Tax expenditures of the CG & $\begin{array}{l}\text { Yes (contemplated in the } \\
\text { Fiscal Pact) } \\
\text { Covers all taxes, and is } \\
\text { calculated for 2003-05 } \\
\text { Cost estimated using } \\
\text { static methods based on } \\
\text { approximations to } \\
\text { exempt tax assessments }\end{array}$ & $\begin{array}{l}\text { Yes } \\
\text { Part IV Draft } \\
\text { PGIEE }\end{array}$ & Paragraph 28 & 2.1 .3 \\
\hline 8. & $\begin{array}{l}\text { Quasi-fiscal activities of } \\
\text { the CG }\end{array}$ & No & No & Paragraph 28 & 2.1 .3 \\
\hline 9. & $\begin{array}{l}\text { Macroeconomic } \\
\text { assumptions }\end{array}$ & $\begin{array}{l}\text { Yes } \\
\text { Part VI of the draft } \\
\text { PGIEE }\end{array}$ & $\begin{array}{l}\text { Yes } \\
\text { Part VI of the } \\
\text { Draft PGIEE }\end{array}$ & Paragraph 34 & 3.1 .3 \\
\hline 10. & $\begin{array}{l}\text { Fiscal risk analysis } \\
\text { /Sensitivity analysis }\end{array}$ & No & No & Paragraph 35 & 3.1 .5 \\
\hline 12. & Financial assets of the CG & $\begin{array}{l}\text { Yes } \\
\text { General Balance Sheet }\end{array}$ & $\begin{array}{l}\text { Yes } \\
\text { End of year } \\
\text { accounts } \\
\text { MINFIN web }\end{array}$ & Paragraph 30 & 2.1 .4 \\
\hline 13. & Sustainability analysis & No & No & Paragraph 35 & 3.1 .1 \\
\hline
\end{tabular}




\begin{tabular}{|c|c|c|c|c|c|}
\hline & Budget or Fiscal Report & $\begin{array}{c}\text { Included in the Budget } \\
\text { or in Reports }\end{array}$ & $\begin{array}{c}\text { Available to the } \\
\text { Public }\end{array}$ & $\begin{array}{l}\text { Paragraph } \\
\text { Referred to }\end{array}$ & $\begin{array}{c}\text { Reference } \\
\text { Code }\end{array}$ \\
\hline 14. & $\begin{array}{l}\text { General government (GG) } \\
\text { budget forecasts }\end{array}$ & No & No & Paragraph 25 & 2.1 .5 \\
\hline 15 . & $\begin{array}{l}\text { Monthly or quarterly } \\
\text { reports on the fiscal results } \\
\text { of the CG }\end{array}$ & $\begin{array}{l}\text { Yes } \\
\text { Monthly, } 15 \text { days after } \\
\text { the end of the month } \\
\text { Every } 4 \text { months to the } \\
\text { CGC }\end{array}$ & $\begin{array}{l}\text { Yes } \\
\text { MINFIN website }\end{array}$ & $\begin{array}{l}\text { Paragraphs } 46 \\
\text { and } 47\end{array}$ & 3.4 .1 \\
\hline 16. & $\begin{array}{l}\text { Monthly or quarterly } \\
\text { reports on the fiscal results } \\
\text { of the GG }\end{array}$ & $\begin{array}{l}\text { No } \\
\text { The budget and the } \\
\text { reports do not cover the } \\
\text { whole of general } \\
\text { government }\end{array}$ & No & Paragraph 46 & 3.4 .1 \\
\hline 17. & $\begin{array}{l}\text { Fiscal accounts; close of } \\
\text { the fiscal year, CG }\end{array}$ & $\begin{array}{l}\text { No } \\
\text { Only for the executive } \\
\text { branch } \\
\text { outturn of the PGIEE } \\
\text { audited annually, within } \\
\text { five months of the end of } \\
\text { the fiscal year }\end{array}$ & $\begin{array}{l}\text { Yes } \\
\text { Only for the } \\
\text { executive branch } \\
\text { congress } \\
\text { website }\end{array}$ & $\begin{array}{l}\text { Paragraphs } 47 \\
\text { and } 48\end{array}$ & 3.4 .2 \\
\hline 18. & $\begin{array}{l}\text { Consolidated fiscal } \\
\text { accounts; end of fiscal } \\
\text { year, GG }\end{array}$ & No & No & $\begin{array}{l}\text { Paragraphs } 47 \\
\text { and } 48\end{array}$ & 3.4 .2 \\
\hline
\end{tabular}

